Nevada

Environmental

Restoration

Project

TECEIVED

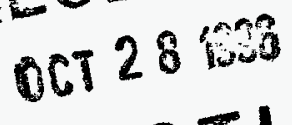
OSTI
DOE/NV-407

UC-700

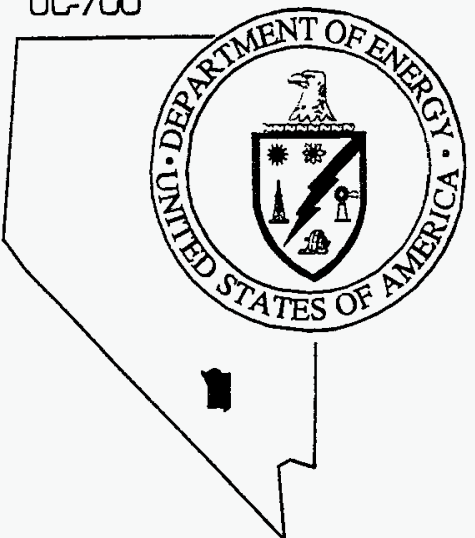

Completion Report for

Well ER-30-1

December 1995

Environmental Restoration

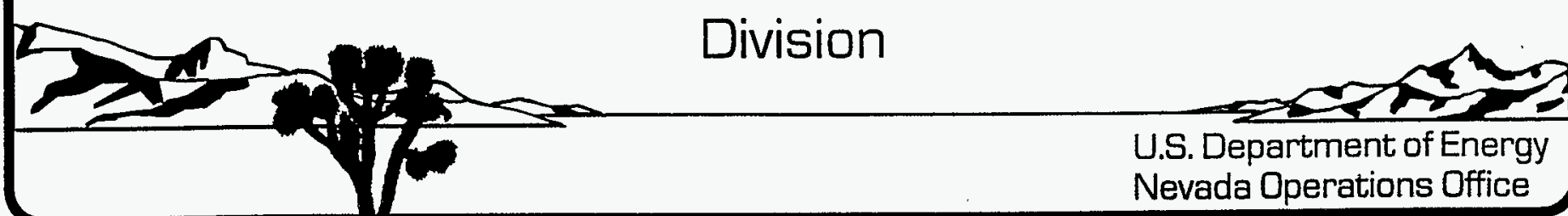


This report has been reproduced from the best available copy. Available in paper copy and microfiche.

Number of pages in this report: 68

DOE and DOE contractors can obtain copies of this report from:

Office of Scientific and Technical Information, P.O. Box 62 ,

Oak Ridge, TN 37831. (615) 576-8401.

This report is publicly available from the Department of Commerce, National Technical Information Service, 5285 Port Royal Road, Springfield, VA 22161. (703) 487-4650. 
This report was prepared as an account of work sponsored by an agency of the United States Government. Neither the United States Government nor any agency thereof, nor any of their employees, makes any warranty, express or implied, or assumes any legal liability or responsibility for the accuracy, completeness, or usefulness of any information, apparatus, product, or pres the would not infringe privately owned rights. Referprocess disciosed, or represents that its use would not ins, or service by trade name, trademark, ence herein to any specific commercial product, process, or service by trade name, tradenark, manufacturer, or otherwise does not necessarily constitute or imply its endorsement, recommendation, or favoring by the United States Government or any agency thereof. The of the and opinions of authors expressed herein do not necessarily state or reflect those of the United States Government or any agency thereof.

\section{COMPLETION REPORT FOR WELL ER-30-1}

Prepared for

DOE Nevada Operations Office

Las Vegas, Nevada

Prepared by

IT CORPORATION

4330 South Valley View Boulevard. Suite 114

Las Vegas, Nevada 89103

December 1995 
DISCLAIMER

Portions of this document may be illegible in electronic image products. Images are produced from the best available original document. 
Approved by: Bobent On. Bangenten Qs.

General Engineer

Environmental Restoration Division
Approved by: Stewen t. Lawrence Subproject Manager

Environmental Restoration Division

Date: $12-19-45$

Date: $12-19-95$

Approved by: Sreph A Meling ton

Stephen A. Mellington

Project Manager

Environmental Restoration Division 


\section{Table of Contents}

List of Figures $\ldots \ldots \ldots \ldots \ldots \ldots \ldots \ldots \ldots \ldots \ldots \ldots \ldots \ldots \ldots \ldots \ldots \ldots \ldots \ldots$

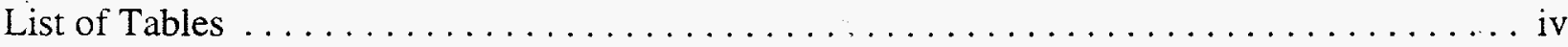

List of Acronyms and Abbreviations $\ldots \ldots \ldots \ldots \ldots \ldots \ldots \ldots \ldots \ldots \ldots \ldots$

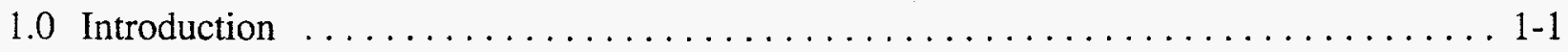

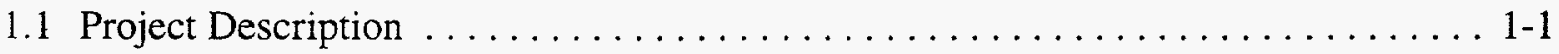

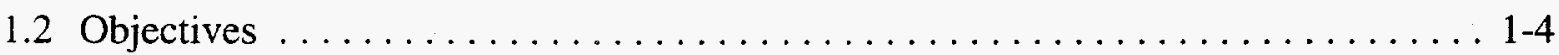

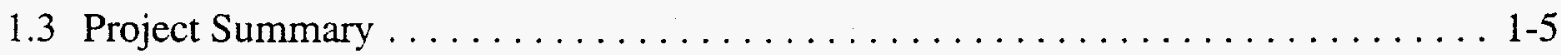

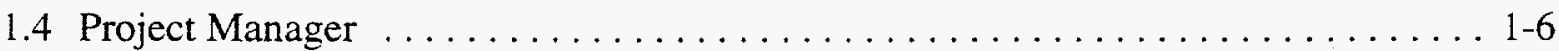

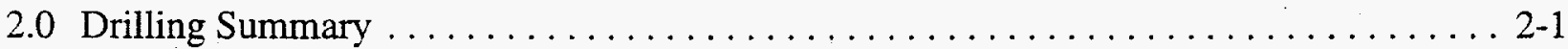

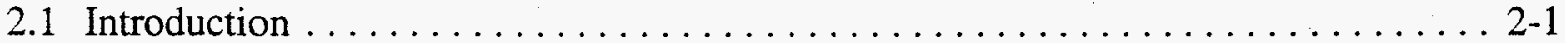

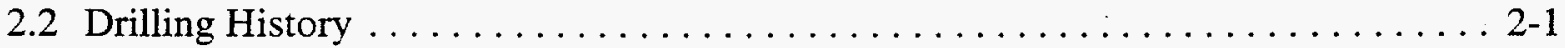

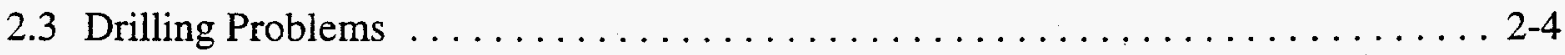

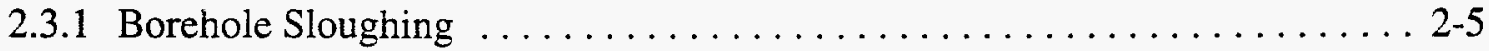

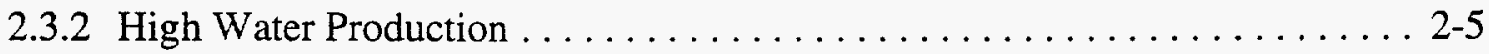

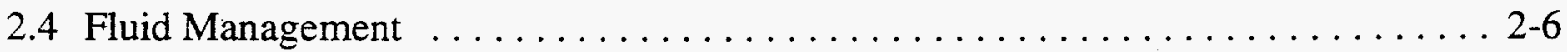

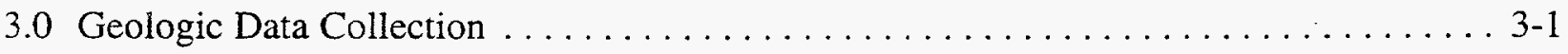

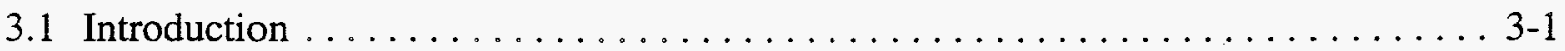

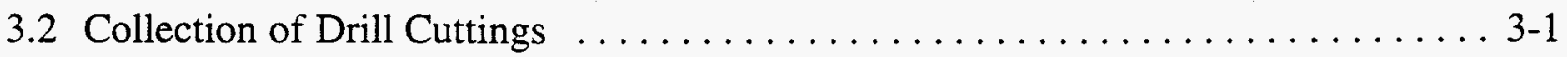

3.3 Sidewall Core Samples . . . . . . . . . . . . . . . . . . . . 3-1

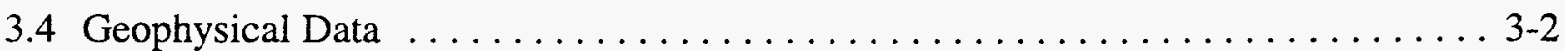

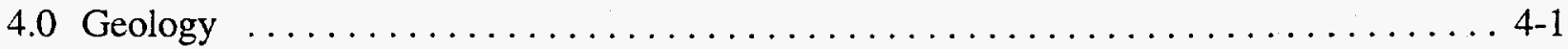

5.0 Hydrology $\ldots \ldots \ldots \ldots \ldots \ldots \ldots \ldots \ldots \ldots \ldots \ldots \ldots \ldots \ldots \ldots \ldots . \ldots \ldots$

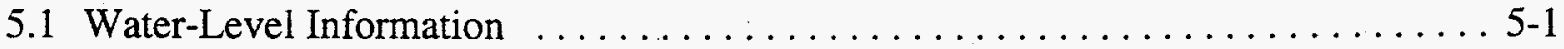

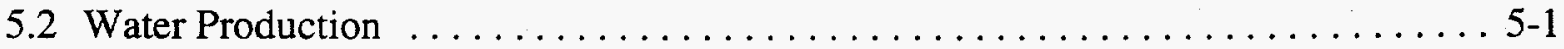

5.3 Time Domain Reflectometry Test . . . . . . . . . . . . . . . 5-1

5.4 Thermal Flow Meter Data $\ldots \ldots \ldots \ldots \ldots \ldots \ldots \ldots \ldots \ldots \ldots \ldots \ldots \ldots \ldots$ 
6.0 Precompletion and Open-Hole Development $\ldots \ldots \ldots \ldots \ldots \ldots \ldots \ldots \ldots \ldots$

7.0 Well Completion $\ldots \ldots \ldots \ldots \ldots \ldots \ldots \ldots \ldots \ldots \ldots \ldots \ldots \ldots \ldots \ldots \ldots$

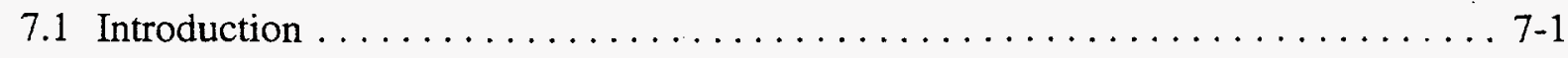

7.2 Well Completion Design . . . . . . . . . . . . . . .

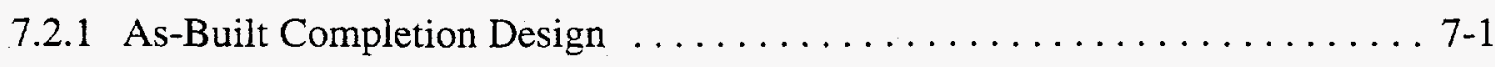

7.2.2 Rationale for Differences between Actual and Proposed Well Design .... . 7-7

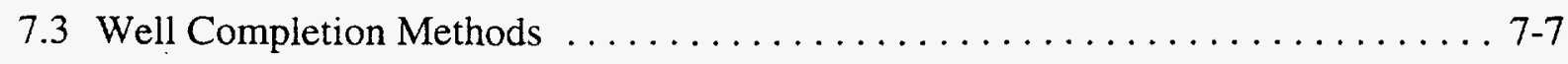

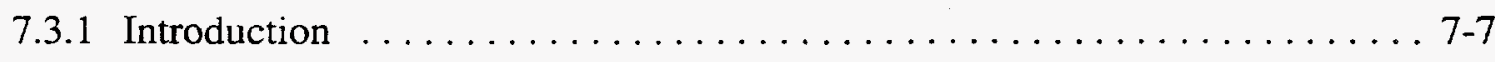

7.3 .2 Completion Method $\ldots \ldots \ldots \ldots \ldots \ldots \ldots \ldots \ldots \ldots \ldots \ldots \ldots \ldots \ldots$

8.0 Actual versus Planned Costs and Scheduling $\ldots \ldots \ldots \ldots \ldots \ldots \ldots \ldots \ldots \ldots$

9.0 Summary, Recommendations, and Lessons Learned . . . . . . . . . . . . 9-1

9.1 Summary . . . . . . . . . . . . . . . .

9.2 Recommendations for Additional Data Interpretation $\ldots \ldots \ldots \ldots \ldots \ldots . . .9-2$

9.3 Lessons Learned $\ldots \ldots \ldots \ldots \ldots \ldots \ldots \ldots \ldots \ldots \ldots \ldots \ldots \ldots . \ldots \ldots \ldots$

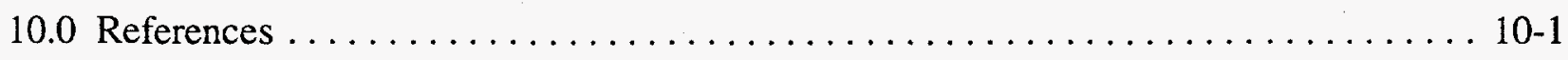

Appendix A - Drilling Data $\ldots \ldots \ldots \ldots \ldots \ldots \ldots \ldots \ldots \ldots \ldots \ldots \ldots \ldots \ldots \ldots \ldots \ldots$

Appendix B - Well ER-30-1 Fluid Management Status Report $\ldots \ldots \ldots \ldots \ldots \ldots \ldots \ldots$ B-1

Appendix C - Stratigraphic and Lithologic Logs of Well ER-30-1 . . . . . . . . . C-1

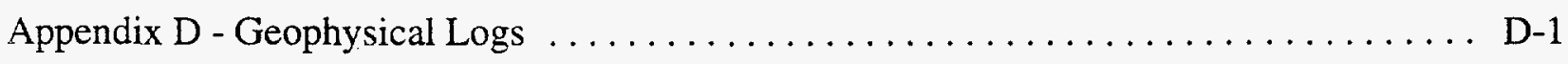




\section{List of Figures}

Number

Title

Page

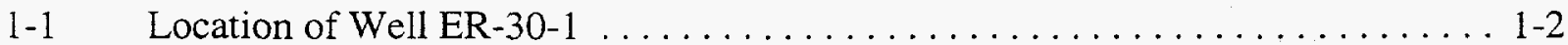

1-2 Map Showing Location of Drill Holes in the Vicinity of Well ER-30-1 . . . . . 1-3

2-1 Well ER-30-1 Drilling and Completion History $\ldots \ldots \ldots \ldots \ldots \ldots \ldots \ldots$

4-1 Well ER-30-1 Predicted versus Actual Stratigraphy $\ldots \ldots \ldots \ldots \ldots \ldots \ldots$. . .

5-1 Water Production versus Lithology for Well ER-30-1 $\ldots \ldots \ldots \ldots \ldots \ldots$

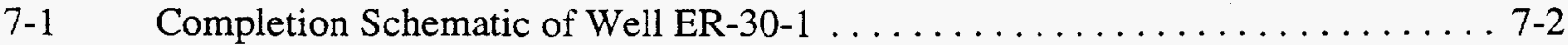

7-2 Well ER-30-1 Wellhead Diagram $\ldots \ldots \ldots \ldots \ldots \ldots \ldots \ldots \ldots \ldots \ldots$

7-3 Completion Configuration for Well ER-30-1, Lower Completion

Zone (String \#1) ...................... $7-5$

7-4 Completion Configuration for Well ER-30-1, Upper Completion

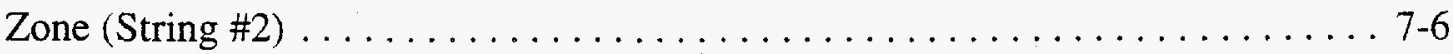

8-1 Planned versus Actual Costs for Drilling of Well ER-30-1 . . . . . . 8-2

8-2 Planned versus Actual Costs for Completion of Well ER-30-1 $\ldots \ldots \ldots . .8$ 


\section{List of Tables}

Number

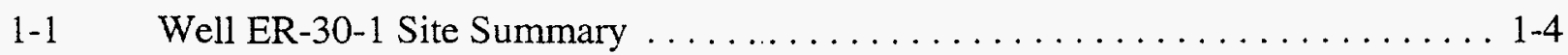

2-1 Abridged Drill Hole Statistics for Well ER-30-1 $\ldots \ldots \ldots \ldots \ldots \ldots \ldots \ldots$ 2-3

3-1 Sidewall Core Samples Collected at Well ER-30-1 $\ldots \ldots \ldots \ldots \ldots \ldots \ldots$

3-2 Well ER-30-1 Geophysical Log Summary $\ldots \ldots \ldots \ldots \ldots \ldots \ldots \ldots \ldots \ldots$

7-1 Well ER-30-1 Construction Summary $\ldots \ldots \ldots \ldots \ldots \ldots \ldots \ldots \ldots \ldots \ldots \ldots \ldots \ldots$

8-1 Well ER-30-1 Planned versus Actual Costs $\ldots \ldots \ldots \ldots \ldots \ldots \ldots . \ldots .1$ 


\section{List of Acronyms and Abbreviations}

$\begin{array}{ll}\text { AWS } & \text { Atlas Wireline Services } \\ \mathrm{cm} & \text { centimeter } \\ \mathrm{ft} & \text { foot } \\ \text { DOE } & \text { U.S. Department of Energy } \\ \text { DRI } & \text { Desert Research Institute } \\ \text { gal } & \text { gallon } \\ \text { gpm } & \text { gallon per minute } \\ \text { in. } & \text { inch } \\ \text { IT } & \text { IT Corporation } \\ \text { km } & \text { kilometer } \\ \ell & \text { liter } \\ \text { lpm } & \text { liter per minute } \\ \text { m } & \text { meter } \\ \text { m } 3 / m i n & \text { cubic meter per minute } \\ \text { mi } & \text { mile } \\ \text { NTS } & \text { Nevada Test Site } \\ \text { od } & \text { outside diameter } \\ \text { REECo } & \text { Reynolds Electrical \& Engineering Co., Inc. } \\ \text { RSN } & \text { Raytheon Services Nevada } \\ \text { TD } & \text { total depth } \\ \text { TDR } & \text { time domain reflectometry } \\ \text { TFM } & \text { thermal flow meter } \\ \text { UGTA } & \text { Underground Test Area } \\ \text { USGS } & \text { U.S. Geological Survey } \\ & \end{array}$




\subsection{Introduction}

\subsection{Project Description}

Well ER-30-1 was drilled for the U.S. Department of Energy (DOE), Nevada Operations Office, in support of the Nevada Environmental Restoration Project at the Nevada Test Site (NTS).

IT Corporation (IT) was the principal environmental contractor for the project. The roles and responsibilities of IT and other contractors involved in the project are described in the Raytheon Services Nevada (RSN) Drilling and Completion Programs (RSN, 1994a,b) and the Underground Test Area Operable Unit Project Management Plan (DOE, 1994a). The Well ER-30-1 investigation is part of the DOE's Underground Test Area (UGTA) Project at the NTS, the goals of which include collecting geological, geophysical, hydrological, and water-chemistry data from new and existing wells to define groundwater migration pathways, rates of migration, and groundwater quality at the NTS. The well will become part of the UGTA monitoring well network.

Well ER-30-1 was drilled as an exploratory well in the north central portion of Area 30, in upper Fortymile Canyon (Figure 1-1). The nearest announced underground nuclear test was conducted approximately 7.3 kilometers $(\mathrm{km})(4.5$ miles [mi]) southwest of the site, at a shallow depth and well above the water table. No radionuclides were expected in Well ER-30-1, so the primary goal of drilling was to obtain geologic and hydrologic data for this relatively unexplored area near the western boundary of the NTS. This site is in the eastern part of the "moat" of the Timber Mountain caldera, an area of relatively thick, but not very extensive, saturated Tertiary gravels and volcanic rocks. The nearest drill holes from which geologic data are available are U-18j\#1 and UE-18t located approximately 6.1 and $8.9 \mathrm{~km}(3.8$ and $5.5 \mathrm{mi})$ to the north, respectively (Figure 1-2).

The Nevada State Planar Coordinates of the site are N837,451.0, E602,275.6 feet ( $\mathrm{ft}$ ). The ground surface elevation at the wellhead is 1.416 .5 meters $(\mathrm{m})(4,647.4 \mathrm{ft})$ above sea level. Additional site summary and survey information is given on Table 1-1.

This report presents construction data and summarizes scientific data gathered during the drilling and well-installation phases of the investigation. Most of the information in this report is preliminary and unprocessed, compiled to summarize the drilling history, geophysical data, and well-installation design. However, the lithologic log is provided in final form. Information on 


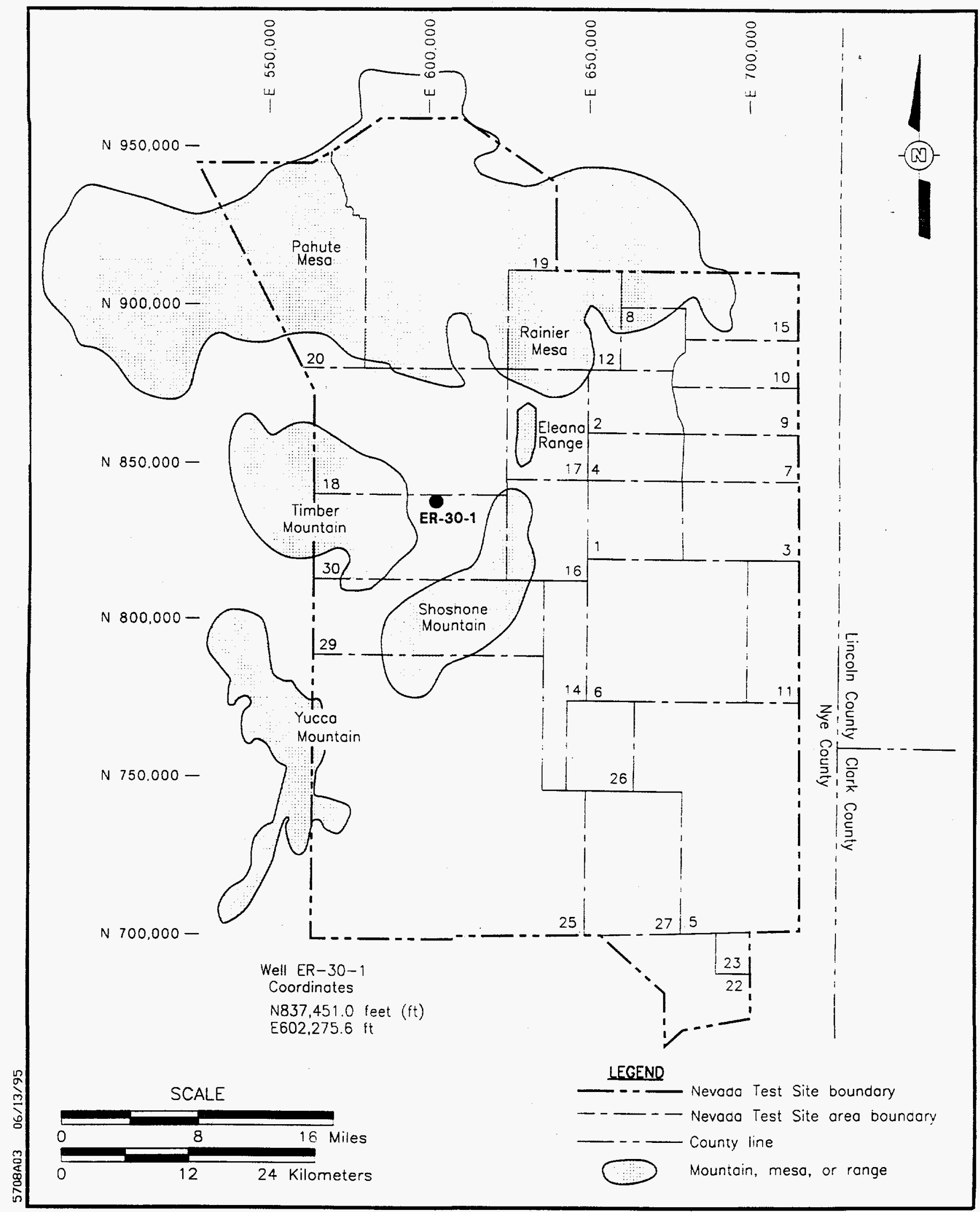

Figure 1-1

Location of Well ER-30-1 


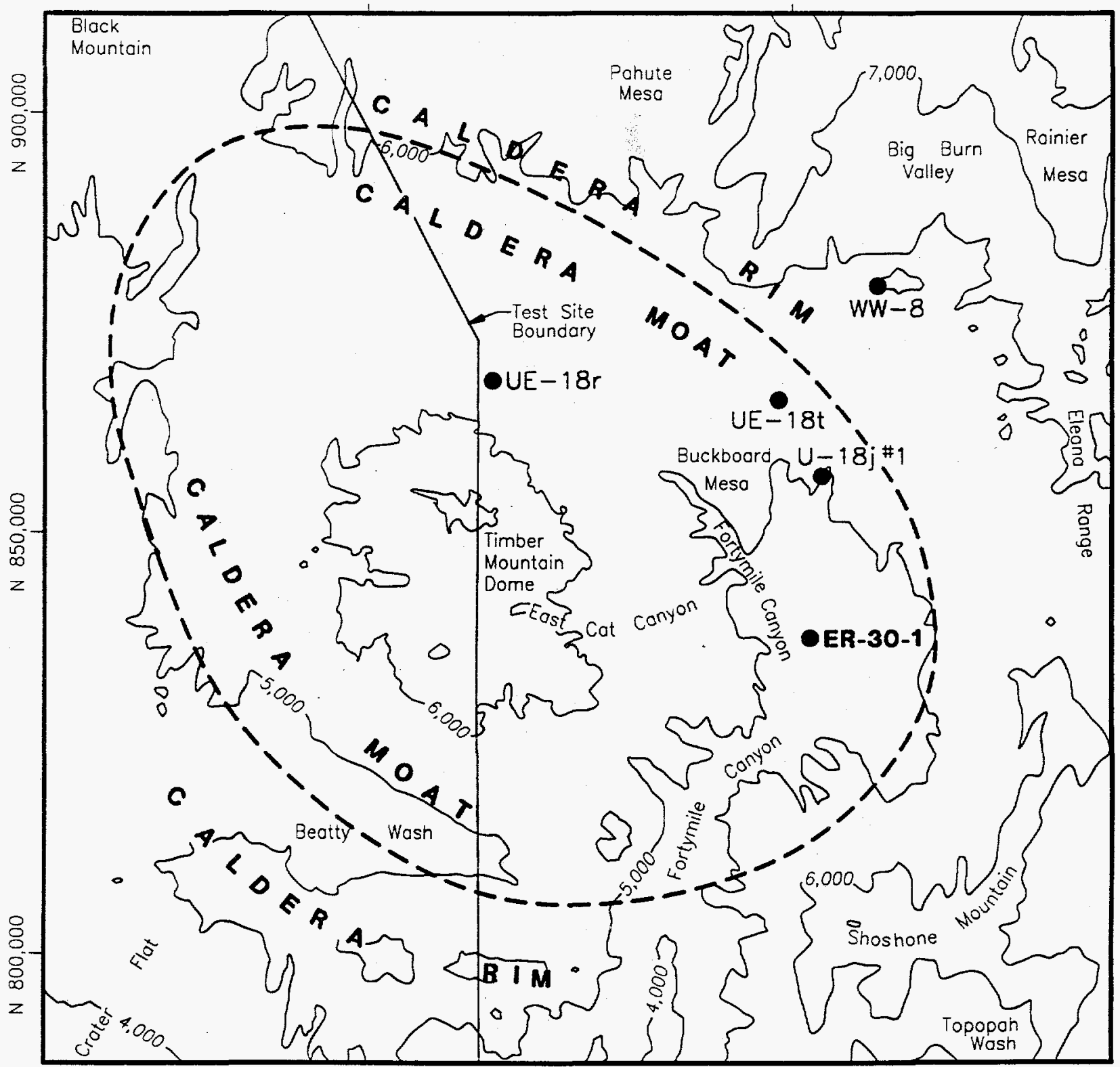

SCALE

$20.000 \quad 40,000$ Feet

$6,000 \quad 12,000$ Meters

Note: Contour interval 1,000 feet

Source: From Corr, 1966

Figure 1-2

Map Showing Location of Drill Holes in the Vicinity of Well ER-30-1 
Table 1-1

Well ER-30-1 Site Summary

\begin{tabular}{|c|c|}
\hline Hole Designation & Well ER-30-1 \\
\hline \multirow[t]{2}{*}{ Site Coordinates ${ }^{a}$} & $\begin{array}{l}\text { Central Nevada State Planar: } \\
\text { N837,451.0, E602,27E } \Xi \text { feet (ft) }\end{array}$ \\
\hline & $\begin{array}{l}\text { Universal Transverse Mercator (Zone } 11 \text { ): } \\
\text { N4,100,463.0, E560,804.5 meters (m) }\end{array}$ \\
\hline Surface Elevation ${ }^{b}$ & $1,416.5 \mathrm{~m}(4,647.4 \mathrm{ft})$ \\
\hline Drilled Depth & $434.6 \mathrm{~m}(1,426 \mathrm{ft})$ \\
\hline Fluid-Level Depth (open borehole) & $137.5 \mathrm{~m}(451 \mathrm{ft})$ \\
\hline Fluid-Level Elevation & $1,279 \mathrm{~m}(4,196 \mathrm{ft})$ \\
\hline
\end{tabular}

1927 North American Datum. Measurement made by RSN Survey.

1929 North American Vertical Datum. Measurement made by RSN Survey.

well development, water levels, aquifer testing, and groundwater analytical sampling will be presented in a future hydrologic data report. Additional information on the results of geologic and geophysical investigations will be presented in one or more analysis and interpretation reports.

\subsection{Objectives}

The primary purpose of Well ER-30-1 was to provide water-level and stratigraphic data to supplement information acquired at other locations within the western NTS. Individual objectives, as discussed in the Well ER-30-1 Drilling/Completion Criteria Document (IT, 1994) include the following:

- Obtain water-level data to refine the understanding of the direction of groundwater flow in the western part of the NTS

- Obtain stratigraphic information regarding caldera-filling deposits in the eastern Timber Mountain caldera moat, as these deposits may influence the groundwater flow regime

- Obtain groundwater samples for determination of local groundwater chemistry

- Detect, if present, perched water (separated from underlying saturated rocks by intervening low-permeability rocks) in the rocks penetrated by the well

- Provide a long-term groundwater monitoring point for this area of the NTS. 


\subsection{Project Summary}

Well ER-30-1 was drilled with conventional rotary drilling techniques using a direct circulation system to a total depth (TD) of $434.6 \mathrm{~m}$ (1,426.0 ft) between February 7, 1994, and March 21, 1994. Following auger-drilling of a 1.22-m (48-inch [in.]) hole for the surface casing, a 44.5-centimeter (cm) (171/2-in.) hole was drilled to $282.2 \mathrm{~m}$ (926 ft). Water production was

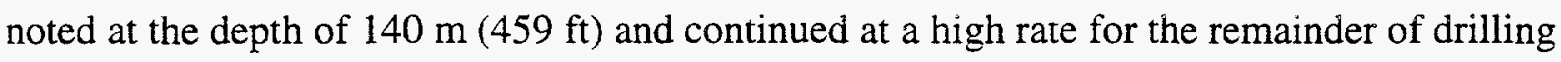
(see Section 5.0). Borehole sloughing problems required cementing and redrilling, and after the second cementing procedure, a $31.1-\mathrm{cm}\left(12^{1 / 4}-\mathrm{in}\right.$.) bit was used to drill through the cement and rock from 246.9 to $434.6 \mathrm{~m}$ ( 810 to $1,426 \mathrm{ft}$ ), at which point circulation was lost and the drilling assembly became stuck on March 16, 1995. The assembly was freed the next day, but obstructions and fill were encountered and drilled out several times during logging. Thus, after three days of effort, the drilled depth of $434.6 \mathrm{~m}(1,426 \mathrm{ft})$ was determined to be acceptable as

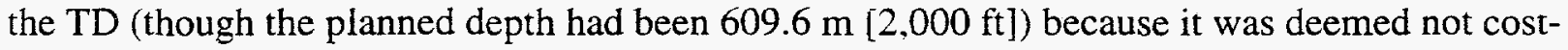
effective to continue drilling efforts in the face of severe sloughing problems. The hole was left

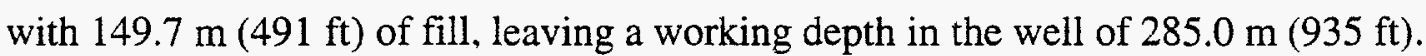

Composite drill cuttings were obtained every three meters from the surface to the TD, and two series of percussion-gun sidewall core samples were taken. Geophysical logs were run periodically during drilling to aid in drilling and construction of the well and after drilling was completed to aid in verification of the geology and the hydrologic characteristics of the units. The hole penetrated Quaternary- and Tertiary-age alluvium and gravel deposits and several Tertiary volcanic units.

Two $27 / 8$-in. piezometer strings, each with a Moyno ${ }^{\circledR}$ pump stator, positioned above the slotted section, were installed in Well ER-30-1. String \#1 (the lowermost piezometer string) was landed off at $239.6 \mathrm{~m}$ (786 ft), with a screened interval located between 227.2 and $233.3 \mathrm{~m}$ (745 to $765 \mathrm{ft})$. This piezometer was gravel-packed and the annulus cemented to $191.5 \mathrm{~m}(628 \mathrm{ft})$.

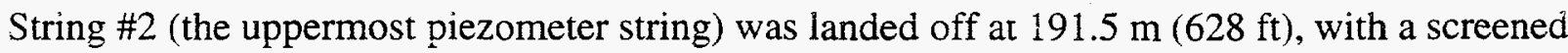
interval located between 179.1 and $185.2 \mathrm{~m}$ (588 to $608 \mathrm{ft}$ ). This piezometer was also gravelpacked, and the annulus was cemented to the surface. Fluid levels were found to be at $138.1 \mathrm{~m}$ (452.9 ft) in String \#1 and $138.0 \mathrm{~m}$ (452.8 ft) in String \#2 on June 21, 1994.

Because drilling of Well ER-30-1 was stopped approximately $175 \mathrm{~m}(574 \mathrm{ft})$ shallower than the

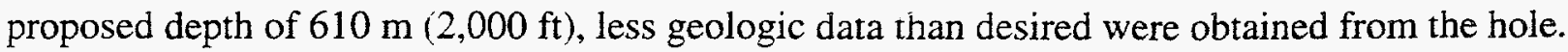
However, the relatively high water table in this well allowed for successful completions at 
shallower depths than originally proposed, and the overall objective of drilling and installing a well to provide hydrologic information of the western part of the NTS has been met.

\subsection{Project Manager}

Inquiries regarding Well ER-30-1 should be directed to Mr. Steven J. Lawrence. UGTA, Project Manager at:

Environmental Restoration Division

DOE/Nevada Operations Office

Post Office Box 98518

Las Vegas, Nevada 89193-8518 


\subsection{Drilling Summary}

\subsection{Introduction}

The drilling requirements for Well ER-30-1 were outlined in the RSN Drilling Program (RSN, 1994a), and changes to the RSN program were documented in RSN Records of Verbal Communication (Appendix A-1). This summary was compiled from the RSN daily rig reports, field notes prepared by the IT Field Representative, and from the RSN ER-30-1 Hole History (RSN, 1995), where complete details of drilling activities can be found. Figure 2-1 is a chart of the drilling and completion history for Well ER-30-1. A summary of drilling statistics for Well ER-30-1 is given in Table 2-1.

\subsection{Drilling History}

Drilling operations at Well ER-30-1 began on February 7, 1994, with the mobilization of a Class VIII auger rig to drill for and set surface casing. A 1.22-m (48-in.) diameter hole was dry-

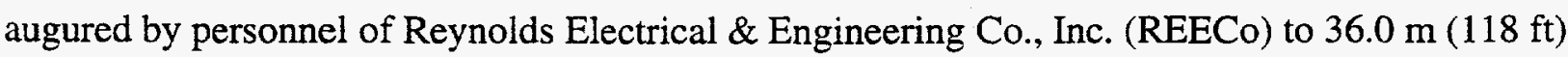
in five stages starting with a $91-\mathrm{cm}$ (36-in.) bit. A 50.8-cm (20-in.) outside-diameter (od) casing was set to $35.6 \mathrm{~m}(117 \mathrm{ft}$ ) on February 11, 1994, and the annulus was cemented to the ground surface on February 14 and 15, 1994. The next day was spent drilling the mouse and rat holes, and work on the hole was suspended until February 25, 1994.

When operations resumed, an International Petroleum Service/Cardwell 500 drill rig was mobilized to the site, and rotary drilling began on March 2, 1994, using direct circulation with bentonite air-foam drilling fluid (Appendix A-4). During the period from March 2 to March 7, 1994, a $44.5 \mathrm{~cm}$ (171/2-in.) hole was drilled to $282.2 \mathrm{~m}$ (926 ft). Water was encountered during drilling on March 4, 1994, at approximately $140 \mathrm{~m}$ (459 ft). Drilling problems due to borehole sloughing below $250 \mathrm{~m}$ ( $820 \mathrm{ft}$ ) necessitated cementing off the zone from 246.9 to $281.9 \mathrm{~m}$ (810 to $925 \mathrm{ft}$ ) on March 8, 1994. Drilling resumed on March 9, 1994, with a 31.1-cm (121/4-in.) bit, and sloughed fill was drilled to the previously attained depth of $282.2 \mathrm{~m}$ ( $926 \mathrm{ft}$ ). Unstable, sloughing borehole conditions persisted, requiring the borehole to be cemented in the interval 248.1 to $295.0 \mathrm{~m}$ (814 to $968 \mathrm{ft}$ ). Drilling continued with the $31.1-\mathrm{cm}\left(12^{1 / 4}-\mathrm{in}\right.$.) bit on March 11, 1994, following completion of cementing operations.

After drilling to $417.3 \mathrm{~m}$ (1,369 ft), drilling activities were shut down to allow trucking of drilling return fluids from the site. Removal of the fluids had become necessary because higher than anticipated groundwater production rates of 1.89 to 2.27 cubic meters per minute $\left(\mathrm{m}^{3} / \mathrm{min}\right)$ 


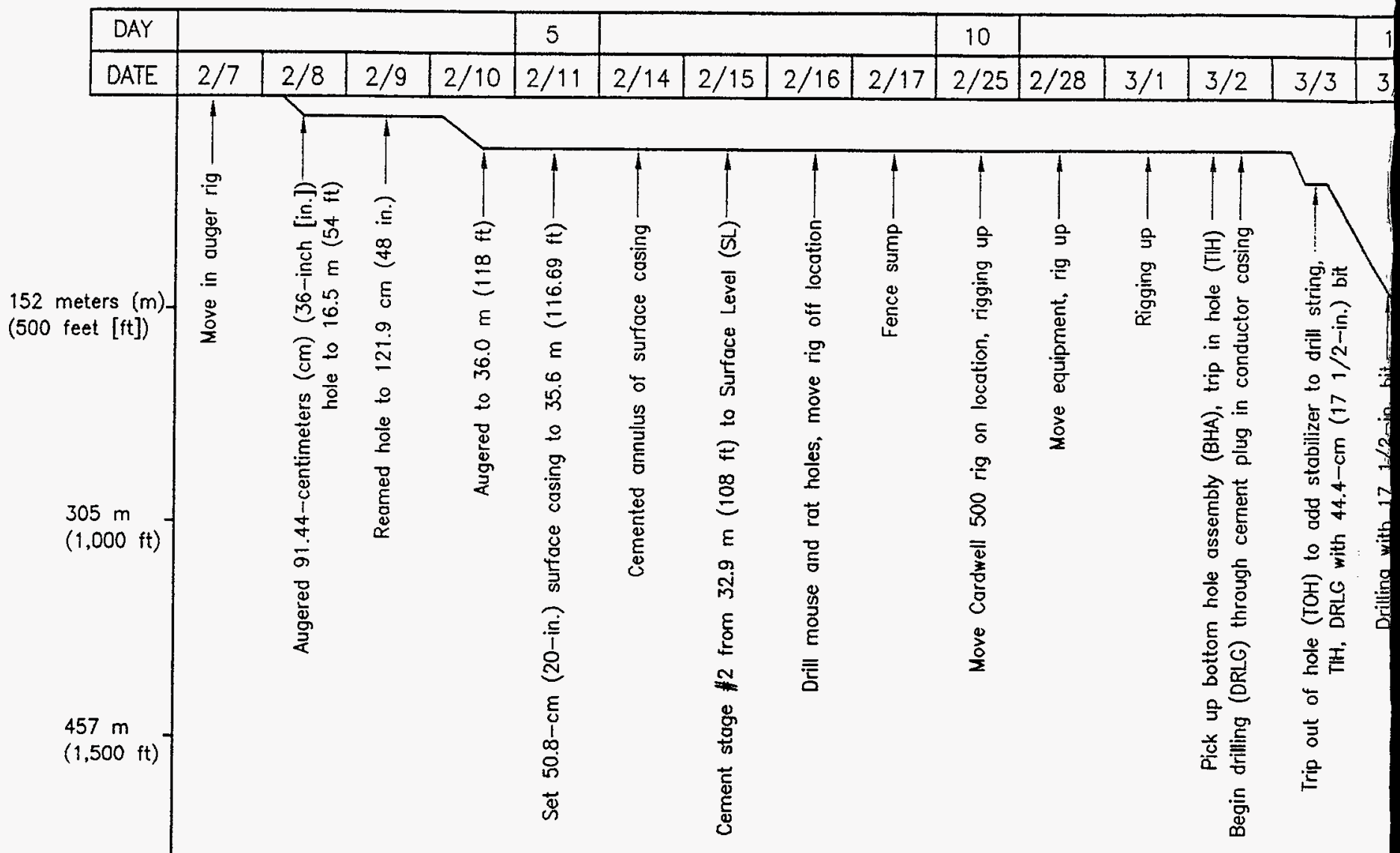

* Note that during ougering and setting surface cosing (from $2 / 7-2 / 17$ ), crew worked day shift only. Storting $2 / 28,24-$ hour operations (Monday-Friday) began with Cardwell 500 rig.

$E R-30-1$

Hole spudded - 02/07/94

Surface hole completed and cased

$02 / 15 / 94$

Drilling of $0.45-m(171 / 2-i n$. ) hole begins

$03 / 02 / 94$

Reached total drilled depth of $434.6 \mathrm{~m}(1,426 \mathrm{ft}) \quad 03 / 17 / 94$

Completed well (with fill to depth of $285.0 \mathrm{~m}$ [935 ft]) $03 / 25 / 94$ 
Table 2-1

Abridged Drill Hole Statistics for Well ER-30-1

\begin{tabular}{|c|c|c|}
\hline $\begin{array}{l}\text { LOCATION DATA: } \text { Coordinates } \\
\qquad \text { Ground Elevation }\end{array}$ & \multicolumn{2}{|c|}{$\begin{array}{l}\text { Central Nevadia State Planar: N837,451.0, E602.275.6 feet }(\mathrm{ft}) \\
\text { Universal Transverse Mercator: N4,100,454.8. E560.803.4 meters }(\mathrm{m}) \\
1,416.5 \mathrm{~m}(4,647.4 \mathrm{ft})\end{array}$} \\
\hline $\begin{array}{l}\text { DRILLING DATA: } \\
\text { Spud Date: } \\
\text { Total Depth (TD): } \\
\text { Date TD Reached: } \\
\text { Date Well Completed: } \\
\text { Original Hole Diameter: }\end{array}$ & $\begin{array}{l}2 / 07 / 94 \text { (auger rig); 3/02/94 (C) } \\
434.6 \mathrm{~m}(1,426 \mathrm{ft}) \\
3 / 17 / 94 \\
3 / 25 / 94 \\
1.22 \mathrm{~m}(48 \text { inches [in.]) from su } \\
44.5 \mathrm{centimeters}(\mathrm{cm})(17.5 \mathrm{in} .) \\
(926 \mathrm{ft}) ; 31.1 \mathrm{~cm}(121 / 4 \mathrm{in} .) \text { from } \\
(1,426 \mathrm{ft}) .\end{array}$ & $\begin{array}{l}\text { to } 36.0 \mathrm{~m}(118 \mathrm{ft}) \\
36.0 \mathrm{~m}(118 \mathrm{ft}) \text { to } 282.2 \mathrm{~m} \\
2.2 \mathrm{~m}(926 \mathrm{ft}) \text { to } 434.6 \mathrm{~m}\end{array}$ \\
\hline $\begin{array}{l}\text { Current Hole Diameter: } \\
\text { (due to cementing) }\end{array}$ & \multicolumn{2}{|c|}{$\begin{array}{l}1.22 \mathrm{~m}(48 \mathrm{in} .) \text { from surface to } 36.0 \mathrm{~m}(118 \mathrm{ft}) ; 44.45 \mathrm{~cm} \\
\left(171 / 2 \text { in.) from } 36.0 \mathrm{~m}(118 \mathrm{ft}) \text { to } 246.8 \mathrm{~m}(810 \mathrm{ft}) ; 31.12 \mathrm{~cm}\left(12 \frac{1 / 4}{\mathrm{in}} .\right)\right. \\
\text { from } 246.8 \mathrm{~m}(810 \mathrm{ft}) \text { to } 434.6 \mathrm{~m}(1,426 \mathrm{ft}) .\end{array}$} \\
\hline Drilling Techniques: & \multicolumn{2}{|c|}{$\begin{array}{l}\text { Dry-hole auger from surface to } 36.0 \mathrm{~m} \text { (118 ft). Air-foam rotary } \\
\text { drilling from } 36.0 \mathrm{~m}(118 \mathrm{ft}) \text { to } 282.2 \mathrm{~m}(926 \mathrm{ft}) \text { using a } 44.5-\mathrm{cm} \\
(171 / 2-\mathrm{in} \text {.) tri-cone bit with conventional circulation. Air-foam rotary } \\
\text { drilling from } 282.2 \mathrm{~m} \text { ( } 926 \mathrm{ft}) \text { to } 434.6 \mathrm{~m}(1,426 \mathrm{ft}) \text { using a } 31.1-\mathrm{cm} \\
\left(12 \frac{1}{4}-\mathrm{in} .\right) \text { tri-cone bit with conventional circulation. }\end{array}$} \\
\hline CASING DATA: & \multicolumn{2}{|c|}{$\begin{array}{l}49.5-\mathrm{cm} \text { (20-in.) casing from surface to } 35.7 \mathrm{~m}(117 \mathrm{ft}) \text {. } \\
\text { No intermediate casing set in hole. }\end{array}$} \\
\hline \multicolumn{3}{|c|}{$\begin{array}{l}\text { WELL COMPLETION DATA: } \\
\text { Two plezometer strings consisting of } 7.3-\mathrm{cm}(27 / 8 \text {-in.) outside diameter tubing, carbon steel in the } \\
\text { unsaturated zone, stainless steel within and extending } 25 \text { to } 30 \mathrm{~m}(80 \text { to } 100 \mathrm{ft}) \text { above the } \\
\text { saturated zone. }\end{array}$} \\
\hline \multirow[b]{2}{*}{$\begin{array}{l}\text { Total Depth: } \\
\text { Depth Slotted Section: } \\
\text { Depth of Gravel Pack: } \\
\text { Depth, Moyno }{ }^{\circledR} \text { Pump Stator: } \\
\text { Water Deptn }\end{array}$} & Lower Piezometer (String \#1) & Upper Piezometer (String \#2) \\
\hline & $\begin{array}{ll}239.6 \mathrm{~m} & (786 \mathrm{ft}) \\
227.2 \text { to } 233.3 \mathrm{~m} & (745 \text { to } 765 \mathrm{ft}) \\
206.3 \text { to } 240.8 \mathrm{~m} & (677 \text { to } 790 \mathrm{ft}) \\
197.9 \text { to } 202.6 \mathrm{~m} & (649 \text { to } 665 \mathrm{ft}) \\
138.1 \mathrm{~m} & (452.9 \mathrm{ft})\end{array}$ & $\begin{array}{l}191.5 \mathrm{~m} \quad(628 \mathrm{ft}) \\
179.1 \text { to } 185.2 \mathrm{~m}(588 \text { to } 608 \mathrm{ft}) \\
123.4 \text { to } 191.5 \mathrm{~m}(405 \text { to } 628 \mathrm{ft}) \\
174.1 \text { to } 178.8 \mathrm{~m}(571 \text { to } 587 \mathrm{ft}) \\
138.0 \mathrm{~m} \quad(452.8 \mathrm{ft})\end{array}$ \\
\hline DRILLING CONTRACTOR: & \multicolumn{2}{|c|}{ Reynolds Electrical \& Engıneering Co., Inc. } \\
\hline GEOPHYSICAL LOGS BY: & \multicolumn{2}{|c|}{$\begin{array}{l}\text { Atlas Wireline Services, Desert Research Institute, Barbour Well } \\
\text { Surveying, Los Alamos National Laboratory/Lawrence Livermore } \\
\text { National Laboratory }\end{array}$} \\
\hline SURVEYING CONTRACTOR & \multicolumn{2}{|l|}{ Raytheon Services Nevada } \\
\hline
\end{tabular}

${ }^{a_{F}}$ Fluid levels as of $06 / 21 / 94$. 
(500 to 600 gallons per minute [gpm]) had filled the existing on-site lined sump and infiltration basin to near capacity. Drilling fluids were trucked to the Well ER-19-1 infiltration basin.

On March 16, 1994, an attempt was made to resume drilling with a downhole Dyna-Drill ${ }^{\mathrm{TM}}$ and a new 31.1-cm (121/4-in.) bit; the attempt was unsuccessful, so drilling resumed with the original 31.1- $\mathrm{cm}\left(12 \frac{1}{4}-\mathrm{in}\right.$.) bit and conventional downhole assembly. Drilling continued to $434.6 \mathrm{~m}$ $(1,426 \mathrm{ft})$, at which point circulation was lost and the drilling assembly became stuck. After approximately 24 hours, efforts to free the drilling assembly were successful, and the assembly was removed from the borehole. The bit was run back into the borehole after a caliper tool could go no deeper than $290.2 \mathrm{~m}$ (952 ft). The obstruction encountered at $290.2 \mathrm{~m}(952 \mathrm{ft}$ ) was drilled through, and the bit was lowered to $384.7 \mathrm{~m}(1,262 \mathrm{ft})$, at which point fill was encountered. No attempt was made to clean the fill, and geophysical logging began, starting with the caliper log from a depth of $384.7 \mathrm{~m}(1,262 \mathrm{ft})$.

On March 21, 1994, after encountering fill at $280.4 \mathrm{~m}$ (920 ft) while logging, the drill string was lowered into the borehole, and fill was cleaned to a depth of $302.4 \mathrm{~m}$ (992 ft). Fill was determined to be reaccumulating at a rate of $1 \mathrm{~m}$ per minute ( $3.3 \mathrm{ft}$ per minute). It was decided to stop at the current depth and complete the well. The drilling assembly was removed from the hole, and geophysical logging continued. The top of the fill was determined to be at $285.0 \mathrm{~m}$ $(935 \mathrm{ft})$.

A graphical depiction of drilling parameters, including penetration rate, revolutions per minute, pump pressure, and weight on the bit, is presented in Appendix A-2. Geophysical logs were run several times during drilling to assess borehole conditions, and the final suite of logs was completed on March 25, 1994.

The Desert Research Institute (DRI) installed time domain reflectometry (TDR) instrumentation in the fluid discharge line at the rig on Well ER-30-1 to determine the effectiveness of TDR in detecting the presence of free water in the drilling effluent. The TDR system and the results of this test are discussed in Section 5.0.

\subsection{Drilling Problems}

Problems experienced during drilling of Well ER-30-1 were associated with two natural conditions encountered in the borehole: (1) sloughing zones in the bedded and welded tuff intervals and (2) very high water production. Measures taken to manage problems associated with these conditions resulted in delays, and ultimately a shallower than planned TD for the hole 
was accepted. The following paragraphs summarize the primary consequences of sloughing and high water production at Well ER-30-1.

\subsubsection{Borehole Sloughing}

Hole problems in two main areas of the borehole caused drilling difficulties. The area from 246.9 to $295.0 \mathrm{~m}$ ( 810 to $968 \mathrm{ft}$ ) required cementing twice due to excessive erosion and sloughing of the borehole. Although this delayed the drilling process, cementing this zone stopped much of the sloughing, and drilling was able to proceed. The zone from 360.0 to $434.6 \mathrm{~m}(1,181$ to $1,426 \mathrm{ft})$ washed out so that the drill pipe became stuck for several hours due to lost circulation and excessive material sloughing around the drill pipe and bit. This portion of the hole continued to slough after repeated attempts to clean the fill during geophysical logging, but cementing was not attempted. The decision to continue drilling with air foam rather than to switch to a heavier mud may have exacerbated the problem, but ultimately will make development of the well much easier.

The drilling program called for setting an intermediate casing point in the upper portion of the Ammonia Tanks Tuff, at an approximate depth of 150 to $200 \mathrm{~m}$ (492 to $656 \mathrm{ft}$ ). The purpose of the intermediate casing was to stabilize any sloughing zones in the upper part of the hole. However, the Ammonia Tanks Tuff was not penetrated until approximately $365 \mathrm{~m}(1,198 \mathrm{ft})$, well below the water table. A casing point at this depth would have eliminated a significant portion of the saturated zone in the well from consideration as a completion zone, so a decision was made not to set intermediate casing.

\subsubsection{High Water Production}

The first evidence of water produced from the borehole was observed at the depth of $140 \mathrm{~m}$ $(459 \mathrm{ft})$. Below the depth of $275 \mathrm{~m}(902 \mathrm{ft})$, the water production during drilling exceeded $1.89 \mathrm{~m}^{3} / \mathrm{min}$ (500 gpm). Thus, for every hour of drilling, roughly 114 cubic meters ( 714 barrels $[30,000$ gallons (gal)]) of fluid were produced in addition to the drilling fluid added to the hole during drilling. On-site pit capacity was nearly reached by March 14, 1995, and drilling was shut down until March 16, 1995, while accumulated drilling fluid and groundwater were hauled to the infiltration pit at Well ER-19-1. Again, use of a heavier mud to try to seal the formation might have relieved this problem to some degree. The anticipation of handling water production of this magnitude as the drill-hole depth increased contributed to the decision to stop drilling before the planned TD was reached. 


\subsection{Fluid Management}

Bentonite air foam. modified to eliminate soda ash (sodium carbonate $\left[\mathrm{Na}_{2} \mathrm{CO}_{3}\right]$ ) from the mixture, was used during drilling of Well ER-30-1 (Appendix A-4). Fluid from the well was discharged into a lined sump and later transferred into an infiltration sump once it had been confirmed that fluid quality objectives were met. When the effluent filled the on-site storage capacity, approximately 827 cubic meters (5,200 barrels [218,400 gal]) of discharge fluid were hauled off site for disposal in Well ER-19-1 infiltration pit.

Drilling effluent was monitored in accordance with the Fluid Management Plan for the Underground Test Area Operable Unit (DOE, 1994b). The results of analyses on samples of drilling fluid collected at Well ER-30-1 during drilling operations indicate that all fluid quality objectives were met.

Appendix B of this report contains a fluid disposition reporting form and final analytical results. The fluid disposition form lists volumes and data from well-construction operations, Stages I through III. The volumes of fluids imported to and produced at Well ER-30-1 were calculated from vacuum-truck delivery tickets and measurements of fluids in the lined sump. The solids produced were calculated using the diameter of the borehole and the depth drilled and take into account hole sloughing, redrill of cemented intervals, and lost circulation. 


\subsection{Geologic Data Collection}

\subsection{Introduction}

This section describes the scurces of geologic data obtained from Well ER-30-1 and the methods of data collection. Obtaining geologic data was one of the primary objectives of Well ER-30-1 because of the scarcity of subsurface data from this part of the NTS and especially from the Timber Mountain moat. Data from Well ER-30-1 were expected to increase understanding of the distribution of the tuffs from the Timbèr Mountain caldera and postcollapse moat-filling sediments, which may have an influence on the groundwater flow regime. Thus, the proper collection of geologic data from Well ER-30-1 was considered fundamental to successful completion of the project. Geologic data collection and sampling at Well ER-30-1 consisted of drill cuttings, sidewall core samples, and geophysical logs.

Geologic data collection, sampling, transfer, and documentation activities were performed in accordance with applicable contractor procedures.

\subsection{Collection of Drill Cuttings}

Composite drill cuttings were collected continuously from Well ER-30-1 at 3.05-m (10-ft) intervals as drilling progressed from the surface to the TD of the well (434.6 $\mathrm{m}[1,426 \mathrm{ft}])$, for a total of 142 samples. The IT Field Representative collected a grab sample from each of the cuttings samples before relinquishing custody to the U.S. Geological Survey (USGS) Core Library via RSN. These samples were examined at the drill site, and the field lithologic descriptions were used in preparation of the final lithologic log for Well ER-30-1 given in Appendix C.

\subsection{Sidewall Core Samples}

After drilling was completed two sets of percussion sidewall cores were collected by Atlas Wireline Services (AWS) on March 22, 1994, to verify the stratigraphy penetrated in the 74.7- to 240.8-m (245- to 790-ft) interval. Core sample depths were determined by the IT Field Representative and the IT Field Manager in consultation with RSN geologists and logging engineers. Samples were taken when lithologic data were needed after analysis of penetrationrate changes, geophysical logs (to identify lithologic boundaries), and caliper logs (for successful operation of the sidewall tool). Because erosion of the borehole wall made retrieval of the sidewall samples difficult, up to four samples were attempted at each sample depth to increase chances of recovery. 
Thirteen 20-millimeter (0.8-in.) diameter sidewall cores were recovered out of 25 attempted. The sidewall cores were transferred to the USGS Core Library in Mercury, Nevada, by RSN. Table 3-1 summarizes sidewall-core sample depths and recovery.

\subsection{Geophysical Data}

Geophysical logs were run at various stages of drilling and well completion to further characterize the lithology, structure, and water content of the formations encountered. Geophysical logs were also run to check hole conditions and to determine the extent of caving, the depth to water prior to cementing, and fluid levels during the course of drilling and to monitor completion progress. All logs run are listed in Table 3-2. Geophysical logs used in geologic interpretation are presented as a composite log in Appendix D. In addition to the "standard" suite of logs, AWS conducted a seismic-check shot survey, Barbour Well Surveying ran a downhole video televiewer camera survey, and DRI collected thermal flow data.

Geophysical logs from Well ER-30-1 are available from RSN in Mercury, Nevada, or the Well ER-30-1 project files maintained by IT in Las Vegas, Nevada. 
Table 3-1

Sidewall Core Samples Collected at Well ER-30-1

\begin{tabular}{|c|c|c|c|}
\hline \multicolumn{4}{|c|}{ Sidewall Cores } \\
\hline $\begin{array}{l}\text { Core Depth } \\
\text { meters (feet) }\end{array}$ & Recovery & $\begin{array}{l}\text { Length Recovered } \\
\text { centimeters (inches) }\end{array}$ & Stratigraphy \\
\hline $74.7(245)$ & Recovered & $3.8(1.5)$ & Alluvium \\
\hline $74.7(245)$ & Recovered & $3.8(1.5)$ & Alluvium \\
\hline $91.4(300)$ & Recovered & $3.8(1.5)$ & Alluvium \\
\hline $91.4(300)$ & Recovered & $3.6(1.4)$ & Alluvium \\
\hline $104.5(343)$ & Recovered & $1.3(0.5)$ & post-caldera moat-filling sediments \\
\hline $123.1(404)$ & Recovered & $2.8(1.1)$ & Basalt of Dome Mt. \\
\hline $123.1(404)$ & Recovered & $2.8(1.1)$ & Basalt of Dome Mt. \\
\hline $139.6(458)$ & Recovered & $2.0(0.8)$ & Basait of Dome Mt. \\
\hline $139.6(458)$ & Unrecovered & 0.0 & -- \\
\hline $159.7(524)$ & Unrecovered & 0.0 & -- \\
\hline $159.7(524)$ & Unrecovered & 0.0 & -. \\
\hline $167.6(550)$ & Unrecovered & 0.0 & -- \\
\hline $167.6(550)$ & Unrecovered & 0.0 & -- \\
\hline $196.3(644)$ & Unrecovered & 0.0 &.- \\
\hline $196.3(644)$ & Unrecovered & 0.0 & -- \\
\hline $218.2(716)$ & Unrecovered & 0.0 & -- \\
\hline $218.2(716)$ & Unrecovered & 0.0 & -- \\
\hline $218.2(716)$ & Unrecovered & 0.0 & -. \\
\hline $218.2(716)$ & Unrecovered & 0.0 & -- \\
\hline $230.4(756)$ & Unrecovered & 0.0 & -- \\
\hline $230.4(756)$ & Recovered & $2.5(1.0)$ & post-caldera moat-filling sediments \\
\hline $230.4(756)$ & Recovered & $3.3(1.3)$ & post-caldera moat-filling sediments \\
\hline $240.8(790)$ & Recovered & $2.3(0.9)$ & Rhyolite of Chukar Canyon \\
\hline $240.8(790)$ & Recovered & $3.3(1.3)$ & Rhyolite of Chukar Canyon \\
\hline $240.8(790)$ & Recovered & $3.6(1.4)$ & Rhyolite of Chukar Canyon \\
\hline
\end{tabular}


Table 3-2

Well ER-30-1 Geophysical Log Summary

(Page 1 of 2)

\begin{tabular}{|c|c|c|c|c|c|c|}
\hline Geophysical Log Type & Log Purpose & $\begin{array}{l}\text { Logging } \\
\text { Service }\end{array}$ & Date Logged & Run Number & $\begin{array}{c}\text { Bottom of Logged } \\
\text { Interval } \\
\text { meters (feet) }\end{array}$ & $\begin{array}{c}\text { Top of Logged Interval } \\
\text { meters (feet) }\end{array}$ \\
\hline $\begin{array}{l}\text { Compensated Acoustilog/ } \\
\text { Gamma Ray }\end{array}$ & $\begin{array}{l}\text { Determination of fracture } \\
\text { characteristics/stratigraphic } \\
\text { correlation }\end{array}$ & $\mathrm{AWS}^{\mathrm{a}}$ & $03 / 21 / 94$ & AC-1/GR-8 & $284.7(934)$ & $140.2(460)$ \\
\hline $\begin{array}{l}\text { Borehole Seismic Analysis } \\
\text { (air gun) }\end{array}$ & Lithologic determination & AWS & $03 / 23 / 94$ & SGG-1 & $280.4(920)$ & $38.1(125)$ \\
\hline Caliper/Gamma Ray & $\begin{array}{l}\text { Hole conditions, cement } \\
\text { volumes/stratigraphic } \\
\text { correlation }\end{array}$ & AWS & $\begin{array}{l}03 / 08 / 94 \\
03 / 09 / 94 \\
03 / 10 / 94 \\
03 / 17 / 94 \\
03 / 18 / 94\end{array}$ & $\begin{array}{l}\text { CA6-1/GR-1 } \\
\text { CA6-2/GR-2 } \\
\text { CA6-3/GR-3 } \\
\text { CA6-4/GR-4 } \\
\text { CA6-5/GR-5 }\end{array}$ & $\begin{array}{c}264.9(869) \\
271.6(891) \\
290.8(954) \\
.283 .2(929) \\
381.9(1,253)\end{array}$ & $\begin{array}{c}16.8(55) \\
209.7(688) \\
14.3(47) \\
15.2(50) \\
15.2(50)\end{array}$ \\
\hline $\begin{array}{l}\text { Compensated Density/Gamma } \\
\text { Ray }\end{array}$ & $\begin{array}{l}\text { Lithologic determination/ } \\
\text { stratigraphic correlation }\end{array}$ & AWS & $03 / 21 / 94$ & CDL-1/GR-7 & $289.0(948)$ & $28.7(94)$ \\
\hline $\begin{array}{l}\text { Downhole-Oriented Color } \\
\text { Video }\end{array}$ & $\begin{array}{l}\text { Borehole examination for } \\
\text { fractures, lithology, and fluid } \\
\text { flow }\end{array}$ & Barbour ${ }^{b}$ & $03 / 24 / 94$ & TV-1 & $285.0(935)$ & 0 \\
\hline $\begin{array}{l}\text { Dual Induction (focused)/ } \\
\text { Gamma Ray }\end{array}$ & $\begin{array}{l}\text { Rock porosity/lithologic } \\
\text { determination }\end{array}$ & AWS & $03 / 21 / 94$ & DIFL-1/GR-6 & $289.0(948)$ & $31.1(102)$ \\
\hline Dual Lateralog/Gamma Ray & $\begin{array}{l}\text { Water saturation (sat. zone)/ } \\
\text { stratigraphic correlation }\end{array}$ & AWS & $03 / 22 / 94$ & DLL-1/GR-12 & $286.0(938)$ & $129.6(425)$ \\
\hline $\begin{array}{l}\text { Epithermal Neutron- } \\
\text { Porosity/Gamma Ray }\end{array}$ & $\begin{array}{l}\text { Total water content/ } \\
\text { stratigraphic correlation }\end{array}$ & $\begin{array}{l}\text { AWS } \\
\text { AWS }\end{array}$ & $\begin{array}{l}03 / 22 / 94 \\
03 / 22 / 94\end{array}$ & $\begin{array}{l}\text { ENP-1/GR-10 } \\
\text { ENP-2/GR-11 }\end{array}$ & $\begin{array}{l}250.6(822) \\
285.0(935)\end{array}$ & $\begin{array}{c}21.0(69) \\
210.3(690)\end{array}$ \\
\hline Fluid Density & Depth to water in borehole & AWS & $\begin{array}{l}03 / 04 / 94 \\
03 / 07 / 94 \\
03 / 08 / 94 \\
03 / 18 / 94\end{array}$ & $\begin{array}{l}\text { DF-1 } \\
\text { DF-2 } \\
\text { DF-3 } \\
\text { DF-4 }\end{array}$ & $\begin{array}{l}154.8(508) \\
155.4(510) \\
157.3(516) \\
143.3(470)\end{array}$ & $\begin{array}{l}138.1(453) \\
135.9(446) \\
131.4(431) \\
119.5(392)\end{array}$ \\
\hline Fraclog/Gamma Ray & $\begin{array}{l}\text { Fracture determination, rock } \\
\text { permeability estimation/ } \\
\text { stratigraphic correlation }\end{array}$ & AWS & $03 / 21 / 94$ & FRAC-1/GR-9 & $282.6(927)$ & $139.6(458)$ \\
\hline
\end{tabular}

Refer to footnotes at end of table. 
Table 3-2

Well ER-30-1 Geophysical Log Summary

(Page 2 of 2)

\begin{tabular}{|c|c|c|c|c|c|c|}
\hline Geophysical Log Type & Log Purpose & $\begin{array}{l}\text { Logging } \\
\text { Service }\end{array}$ & Date Logged & Run Number & $\begin{array}{c}\text { Bottom of Logged } \\
\text { Interval } \\
\text { meters (feet) }\end{array}$ & $\begin{array}{l}\text { Top of Logged Interval } \\
\text { meters (feet) }\end{array}$ \\
\hline Gyroscopic Survey & Borehole deviation & $\mathrm{BHI}^{\mathrm{C}}$ & $05 / 11 / 94$ & DRG-1 & $194.5(638)$ & 0 \\
\hline Percussion Gun Sidewall Core & $\begin{array}{l}\text { Geologic samples, } \\
\text { geophysical log calibration }\end{array}$ & AWS & $03 / 22 / 94$ & SGUN-1, 2 & $240.8(790)$ & $74.7(245)$ \\
\hline $\begin{array}{l}\text { Photon Annulus Investigation } \\
\text { (nuclear) }\end{array}$ & $\begin{array}{l}\text { Omnidirectional density (check } \\
\text { for cement and/or fluid } \\
\text { location) }\end{array}$ & AWS & $\begin{array}{l}03 / 08 / 94 \\
03 / 09 / 94 \\
03 / 10 / 94 \\
03 / 10 / 94 \\
03 / 24 / 94 \\
03 / 24 / 94 \\
03 / 25 / 94 \\
03 / 25 / 94\end{array}$ & $\begin{array}{l}\text { AIN-1 } \\
\text { AIN-2 } \\
\text { AIN-3 } \\
\text { AIN-4 } \\
\text { AIN-5 } \\
\text { AIN-6 } \\
\text { AlN-7 } \\
\text { AIN-8 }\end{array}$ & $\begin{array}{l}252.7(829) \\
254.2(834) \\
277.1(909) \\
268.5(881) \\
246.3(808) \\
197.2(647) \\
196.0(643) \\
190.2(624)\end{array}$ & $\begin{array}{l}235.3(772) \\
238.4(782) \\
255.4(838) \\
225.6(740) \\
206.7(678) \\
98.8 \quad(324) \\
88.4 \quad(290) \\
0\end{array}$ \\
\hline Spectral Gamma Ray & $\begin{array}{l}\text { Stratigraphic correlation, } \\
\text { mineralogy, natural radiation }\end{array}$ & AWS & $03 / 18 / 94$ & SGR-1 & $381.0(1,250)$ & $30.5(100)$ \\
\hline Temperature & Groundwater temperature & $\begin{array}{l}\text { AWS } \\
\text { AWS }\end{array}$ & $\begin{array}{l}03 / 18 / 94 \\
03 / 21 / 94\end{array}$ & $\begin{array}{l}\text { TL-1 } \\
\text { TL-2 }\end{array}$ & $\begin{array}{c}383.4(1,258) \\
284.1(932)\end{array}$ & $\begin{array}{l}26.8(88) \\
26.2(86)\end{array}$ \\
\hline $\begin{array}{l}\text { Thermal Flow (with } \\
\text { temperalure, electrical } \\
\text { conductivity, and pH) }\end{array}$ & $\begin{array}{l}\text { Rate/direction of groundwater } \\
\text { flow }\end{array}$ & $\mathrm{DRI}^{\mathrm{d}}$ & 03/22/94 & 1 & $289.3(949)$ & $139.0(456)$ \\
\hline Total Magnetic intensity & Stratigraphic correlation & LANL/LLNL $^{\theta}$ & 03/22/94 & MPP-1 & $288.0(945)$ & $36.0(118)$ \\
\hline
\end{tabular}

Atlas Wireline Services

Barbour Well Surveying

Baker Hughes INTEO

Desert Research institute

Eos Alamos National Laboratory/Lawrence Livermore National Laboratory 


\subsection{Geology}

Well ER-30-1 was drilled within the moat of the Timber Mountain caldera and penetrated $434.6 \mathrm{~m}(1,426 \mathrm{ft})$ of volcanic rocks and associated sediments. IT personnel prepared field lithologic descriptions of the cuttings and sidewall cores, and selected samples were sent to Los Alamos National Laboratory for petrographic and mineralogic analysis (Warren, 1994). Using these data and incorporating analysis of geophysical data, RSN geologists prepared the final lithologic and stratigraphic logs presented in Appendix C.

Quaternary alluvium and Tertiary-age post-caldera, moat-filling sediments were penetrated from

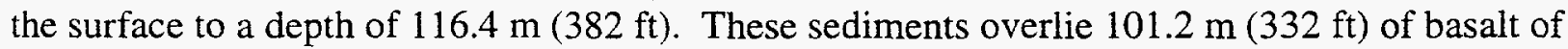
Dome Mountain, which was penetrated between 116.4 and $217.6 \mathrm{~m} \mathrm{(382} \mathrm{to} 714 \mathrm{ft}$ ). An additional $23.2 \mathrm{~m}$ (76 ft) of post-caldera, moat-filling sediments were penetrated below the basalt of Dome Mountain, from 217.6 to $240.8 \mathrm{~m}$ ( 714 to $790 \mathrm{ft}$ ). These sediments in turn overlie $48.8 \mathrm{~m}$ (160 ft) of bedded tuffs of the rhyolite of Chukar Canyon, which was penetrated between 240.8 and $289.6 \mathrm{~m}$ (790 to $950 \mathrm{ft}$ ). Another basalt flow, the basalt of Chukar Canyon, was penetrated below the bedded tuffs, between 289.6 and $365.2 \mathrm{~m}$ (950 to $1,198 \mathrm{ft}$ ). This $75.6-\mathrm{m}$ (248-ft) thick basalt flow was deposited on moderately welded ash-flow tuff of the mafic-rich portion of Ammonia Tanks Tuff, which makes up the rest of the stratigraphic section encountered in Well ER-30-1.

The geology encountered at Well ER-30-1 differed from that predicted prior to drilling (IT, 1994). The most significant differences are the presence of two basalt flows above the Ammonia Tanks Tuff and the presence of Ammonia Tanks Tuff $205 \mathrm{~m}$ (674 ft) deeper than expected. Such differences between predicted and actual geology encountered at Well ER-30-1 are not surprising for two reasons: (1) relationships between volcanic and sedimentary processes associated with caldera formation and collapse can be very complex, and (2) very few drill holes are located nearby to provide geologic data upon which to base predictions. The stratigraphic contacts are shown compared with the predicted stratigraphy on Figure 4-1 (IT, 1994). 


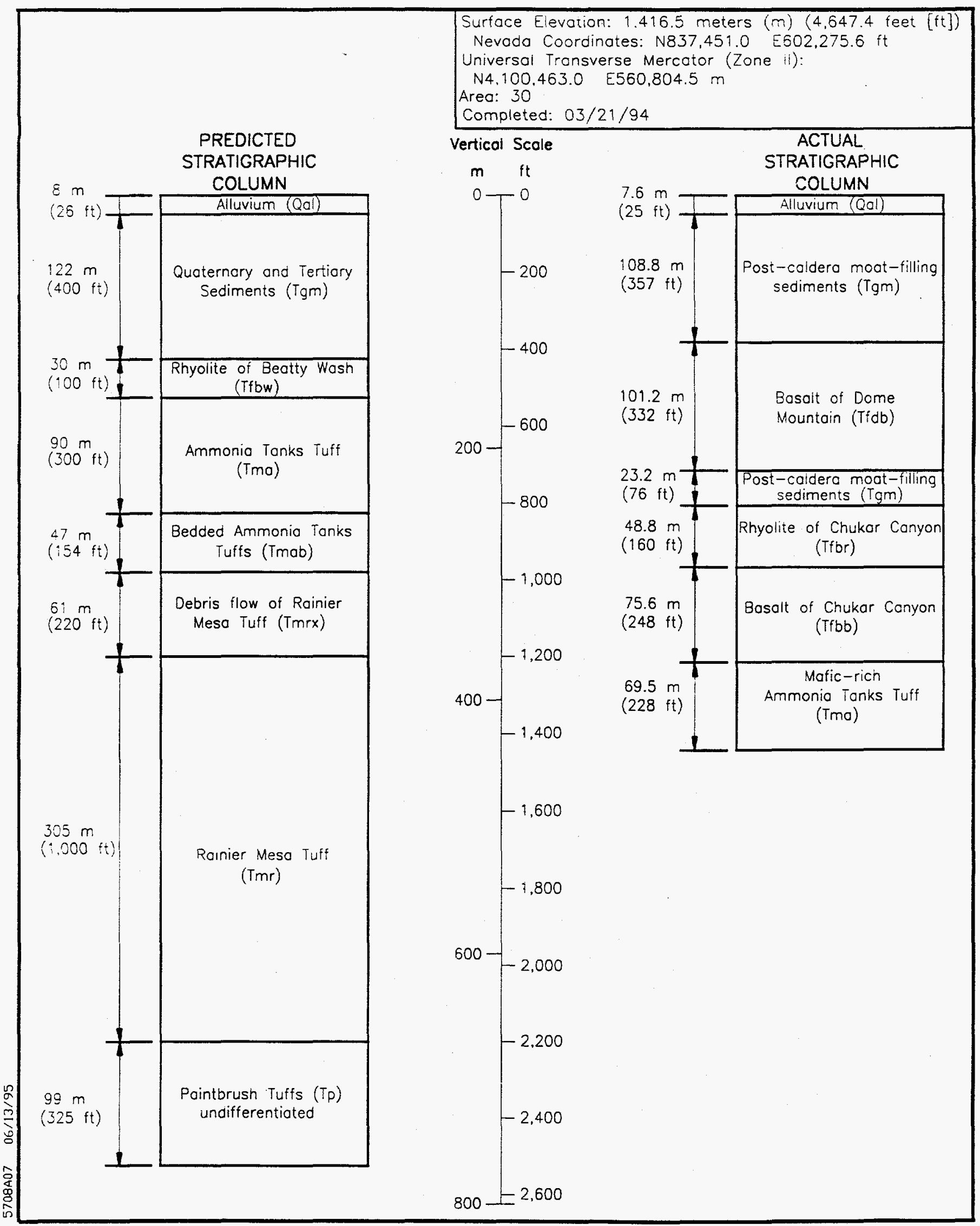

Figure 4-1

Well ER-30-1 Predicted versus Actual Stratigraphy 


\subsection{Hydrology}

\subsection{Water-Level Information}

The depth to water at Well ER-30-1 was projected to be $170 \pm 30 \mathrm{~m}(560 \pm 100 \mathrm{ft}$ ), based on sparse hydrologic data for this region (IT, 1994). Drilling with air foam produced dry returns in the unsaturated zone, which enabled water to be detected almost immediately upon drilling through the water table. Groundwater was detected during drilling as eariy as $140 \mathrm{~m}$ (459 $\mathrm{ft})$ by

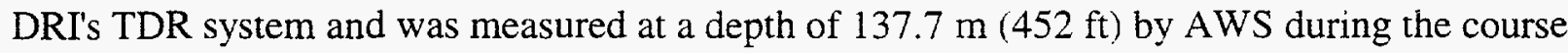
of well-construction logging. Observations made on June 21, 1994, indicated fluid levels of $138 \mathrm{~m}(453 \mathrm{ft})$ in both piezometer strings.

\subsection{Water Production}

Below the depth of $275 \mathrm{~m}$ (902 ft), water production during drilling exceeded $1.8 \mathrm{~m}^{3} / \mathrm{min}$ (500 gpm). Thus, for every hour of drilling, the hole produced approximately $114 \mathrm{~m}^{3}$ $(30,000 \mathrm{gal})$ of water. The high volume of water produced from the borehole was due to the inflow of water to the borehole from several highly permeable water producing zones. Water production rates encountered during drilling are shown in Figure 5-1.

\subsection{Time Domain Reflectometry Test}

Time domain reflectometry instrumentation designed to detect the presence of water in the drilling effluent was tested by DRI during drilling of Well ER-30-1. The sensor was a modified two-wire TDR probe designed to fit within the drill rig's fluid discharge line. Time domain

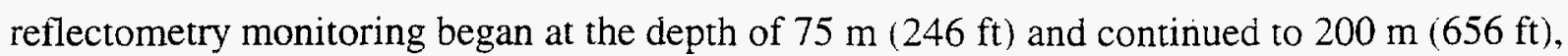
where the well began to produce visually detectable amounts of water. The TDR response indicated wetter fluid starting at approximately $140 \mathrm{~m}(459 \mathrm{ft})$, but below $160 \mathrm{~m}(525 \mathrm{ft})$, the readings indicated drier returns. By analyzing the drill-fluid pump rate in conjunction with the TDR data. DRI estimated that the water table was penetrated at approximately $140 \mathrm{~m}(459 \mathrm{ft})$. Desert Research Institute concluded that without the pump-stroke measurements, TDR data alone were not a useful indicator of water-table penetration (Hokett et al.. 1994).

\subsection{Thermal Flow Meter Data}

Desert Research Institute personnel made thermal flow meter (TFM) measurements at seven locations in the ER-30-1 drill hole. Temperature, electrical conductivity, and $\mathrm{pH}$ were also measured for use in analysis of the TFM data. These measurements were made in the effort to 


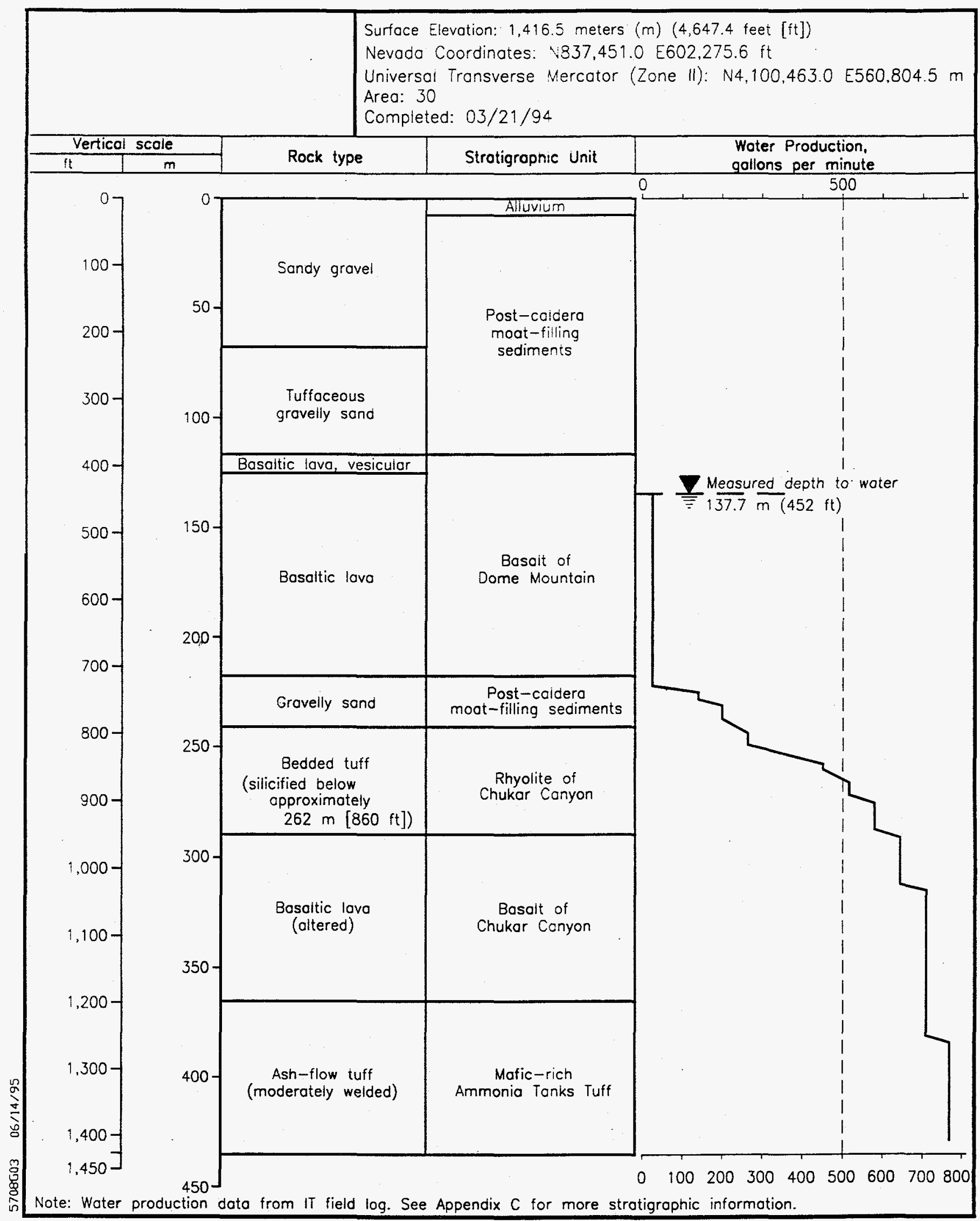

Figure 5-1

Water Production versus Lithology for Well ER-30-1 
identify borehole fluid variability, which may indicate inflow and outflow zones, and to measure the water level. Analysis of the TFM and accompanying data indicated downward flow within the borehole from the water table to $164 \mathrm{~m}(538 \mathrm{ft}$ ) and gradually decreasing upward flow from the bottom of the hole to $173 \mathrm{~m}$ ( $567 \mathrm{ft}$ ). Desert Research Institute concluded from this result that water was exiting the borehole between 164 and $173 \mathrm{~m}$ (538 to $567 \mathrm{ft}$ ) (Lyles et al., 1994). 


\subsection{Precompletion and Open-Hole Development}

Precompletion open-hole development was not attempted in Well ER-30-1 due to unstable hole conditions. 


\subsection{Well Completion}

\subsection{Introduction}

The objective of well completion is to hydraulically isolate specific water-producing zones within a single borehole in order to collect potentiometric and water-chemistry data from the desired producing zones. Completion activities at Well ER-30-1 began on March 24, 1994, and were concluded on March 25, 1994. Figure 7-1 is a schematic of the final well-completion design for Well ER-30-1, Table 7-1 is a construction summary for the well, and Figure 7-2 shows a plan view and profile of the wellhead surface completion.

Well ER-30-1 was proposed as a dual-completion well to evaluate hydrologic characteristics of two separate hydrologic regimes: a shallow zone either within volcanic units or overlying saturated tuffaceous alluvial material and a second zone within deeper volcanic units. However. because the hole was drilled shallower than planned and because the lower $150 \mathrm{~m}(491 \mathrm{ft})$ of the hole was blocked by fill material, both piezometer strings were set higher than planned, as described in this section.

\subsection{Well Completion Design}

\subsubsection{As-Built Completion Design}

Both Strings \#1 and \#2 are composed of stainless steel, including one slotted section in each piezometer, from the bottom of the string to just above the water level, and then flush-joint carbon-steel casing to the surface. Moyno ${ }^{\mathbb{B}}$ pump stators were permanently installed in the piezometer strings so that well development and groundwater sampling would require only insertion of the pump rotor and rods. Detailed diagrams of the completion zones for String \#1 and $\# 2$ are shown on Figures 7-3 and 7-4, respectively, and the string compositions summarized here are listed on Table 7-1.

The lower section of String \#1 is $27 / 8$-in. od Type 304 stainless-steel tubing to approximately $31.4 \mathrm{~m}$ (103 ft) above static water level (based on a static water level in the hole of

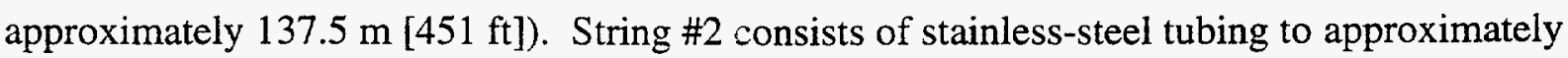

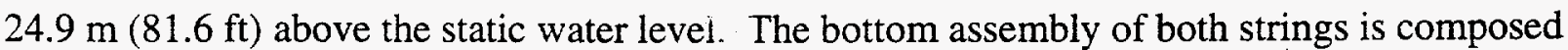
of a $6.1-\mathrm{m}$ (20-ft) Schedule 40, stainless-steel, bull-nosed tailpipe as a sediment trap, followed by a $6.1-\mathrm{m}$ (20-ft) Schedule 40, stainless-steel, slotted section. In both strings, the stainless-steel section is followed by $9.6-\mathrm{m}$-long ( 31.5 -ft-long), $27 / 8$-in. od carbon-steel joints to the surface. 


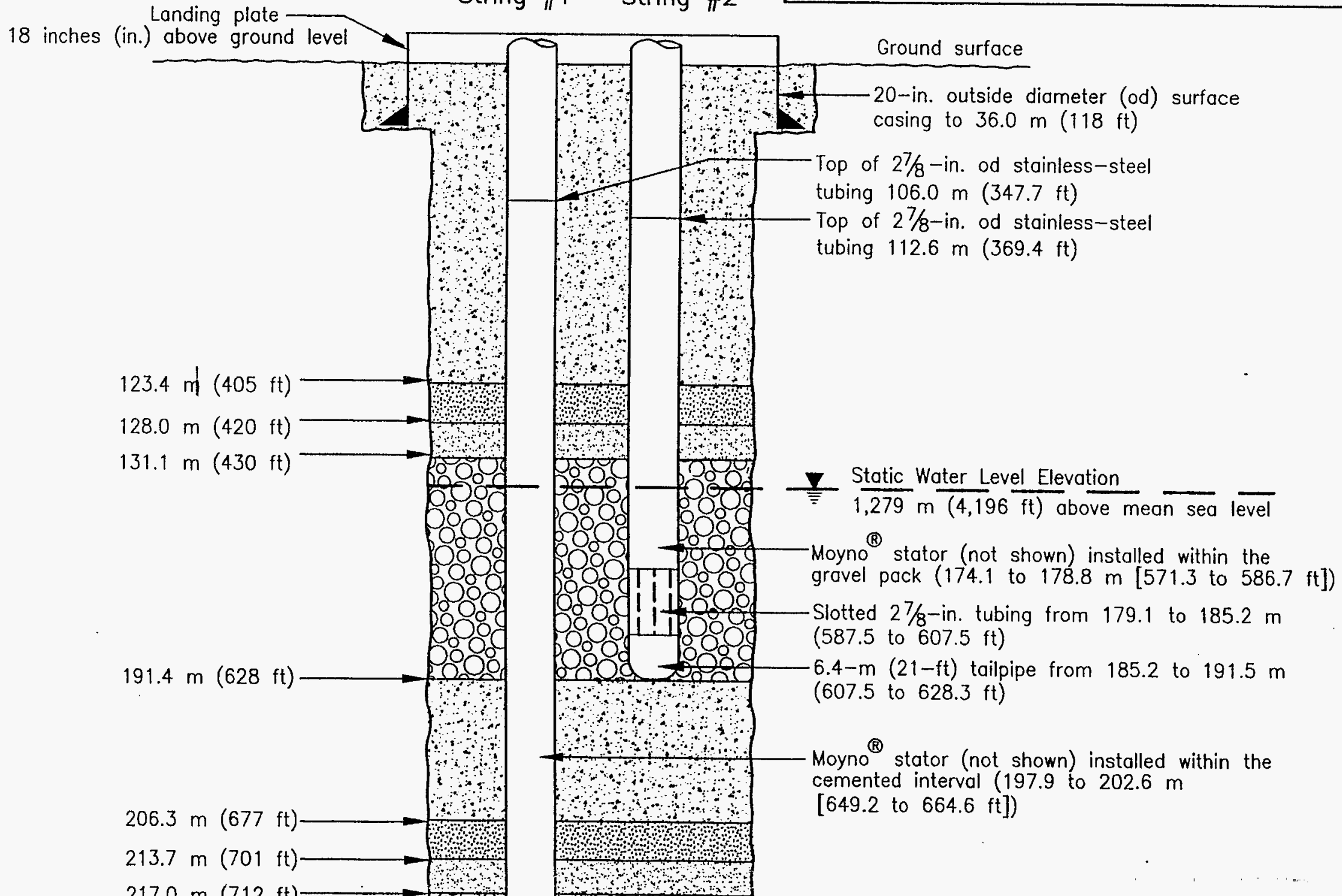




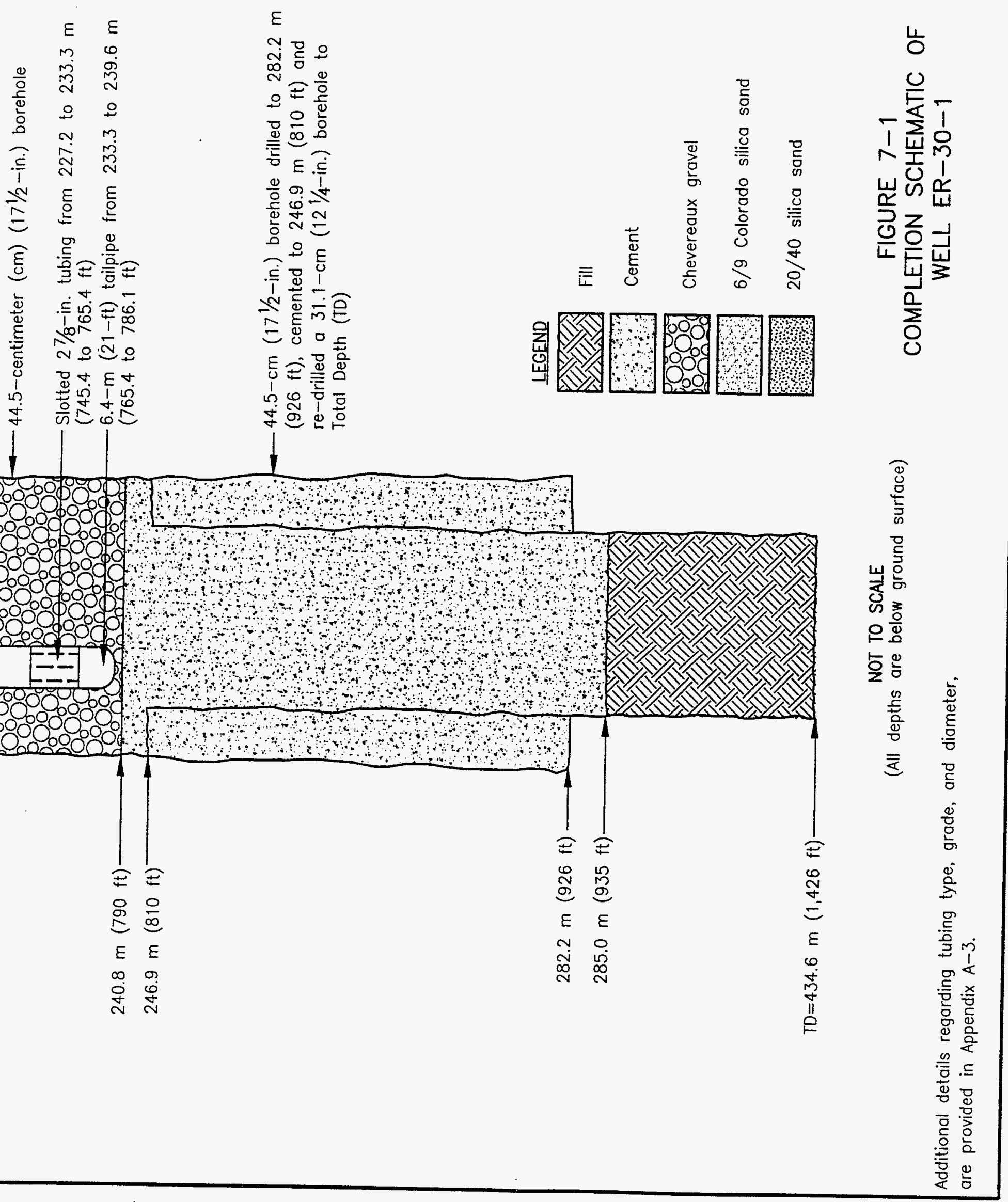


Table 7-1

Well ER-30-1 Construction Summary

\begin{tabular}{|c|c|c|c|c|c|c|}
\hline \multirow{2}{*}{ String } & \multicolumn{3}{|c|}{ Tubing $^{a}$} & \multirow{2}{*}{ Cement } & \multirow{2}{*}{ Sand/Gravel } & \multirow{2}{*}{$\begin{array}{l}\text { Depth to } \\
\text { Fluid }^{\text {b }}\end{array}$} \\
\hline & Carbon Steel & & Steel & & & \\
\hline \multirow{5}{*}{$\# 1$} & \multirow{5}{*}{$\begin{array}{l}\text { Ground surface to } \\
106.0 \text { meters }(\mathrm{m})(347.7 \text { feet }[\mathrm{ft}])\end{array}$} & \multirow{5}{*}{$\begin{array}{l}106.0 \text { to } 239.6 \mathrm{~m} \\
(347.7 \text { to } 7861 \mathrm{ft})\end{array}$} & $\begin{array}{c}\text { Blank } \\
106.0 \text { to } 197.9 \mathrm{~m} \\
(347.7 \text { to } 649.2 \mathrm{ft})\end{array}$ & \multirow{5}{*}{$\begin{array}{c}\text { Type II }+2 \% \mathrm{CaCl}_{2} \\
240.8 \text { to } 285.0 \mathrm{~m} \\
(790 \text { to } 935 \mathrm{ft}) \\
191.5 \text { to } 206.3 \mathrm{~m} \\
(628 \text { to } 677 \mathrm{ft})\end{array}$} & $\begin{array}{c}20 / 40 \text { sand } \\
206.3 \text { to } 213.7 \mathrm{~m} \\
(677 \text { to } 701 \mathrm{ft})\end{array}$ & \multirow{5}{*}{$\begin{array}{l}\text { Fluid level } \\
138.1 \mathrm{~m} \\
(452.9 \mathrm{ft})\end{array}$} \\
\hline & & & $\begin{array}{l}\text { Moyno }^{8} \text { stator }^{c} \\
197.9 \text { to } 202.6 \mathrm{~m} \\
(649.2 \text { to } 664.6 \mathrm{ft})\end{array}$ & & $\begin{array}{c}\text { 6-9 sand } \\
213.7 \text { to } 217.0 \mathrm{~m}\end{array}$ & \\
\hline & & & $\begin{array}{c}\text { Blank } \\
202.6 \text { to } 227.2 \mathrm{~m} \\
(664.6 \text { to } 745.4 \mathrm{ft})\end{array}$ & & (701 to $712 \mathrm{ft}$ ) & \\
\hline & & & $\begin{array}{c}\text { Slotted } \\
227.2 \text { to } 233.3 \mathrm{~m} \\
(745.4 \text { to } 765.4 \mathrm{ft})\end{array}$ & & \multirow{2}{*}{$\begin{array}{c}\text { Chevereaux gravel } \\
217.0 \text { to } 240.8 \mathrm{~m} \\
(712 \text { to } 790 \mathrm{ft})\end{array}$} & \\
\hline & & & $\begin{array}{l}\text { Bull-nosed tallpipe } \\
233.3 \text { to } 239.6 \mathrm{~m} \\
(765.4 \text { to } 786.1 \mathrm{ft})\end{array}$ & & & \\
\hline \multirow{5}{*}{$\# 2$} & \multirow{5}{*}{$\begin{array}{l}\text { Ground surface to } \\
112.6 \mathrm{~m}(369.4 \mathrm{ft})\end{array}$} & \multirow{5}{*}{$\begin{array}{l}112.6 \text { to } 191.5 \mathrm{~m} \\
(369.4 \text { to } 628.3 \mathrm{ft})\end{array}$} & $\begin{array}{c}\text { Blank } \\
112.6 \text { to } 1741 \mathrm{~m} \\
(369.4 \text { to } 571.3 \mathrm{ft})\end{array}$ & \multirow{5}{*}{$\begin{array}{c}\text { Type } .11+2 \% \mathrm{CaCl}_{2} \\
0 \text { to } 123.4 \mathrm{~m} \\
(0 \text { to } 405 \mathrm{ft})\end{array}$} & $\begin{array}{c}20 / 40 \text { sand } \\
123.4 \text { to } 128.0 \mathrm{~m} \\
(405 \text { to } 420 \mathrm{ft})\end{array}$ & \multirow{5}{*}{$\begin{array}{c}\text { Date } \\
06 / 21 / 94 \\
\text { Fluid level } \\
138.0 \mathrm{~m} \\
(452.8 \mathrm{ft})\end{array}$} \\
\hline & & & $\begin{array}{l}\text { Moyno stator } \\
174.1 \text { to } 178.8 \mathrm{~m} \\
(571.3 \text { to } 586.7 \mathrm{ft})\end{array}$ & & $\begin{array}{c}6-9 \text { sand } \\
128.0 \text { to } 131.1 \mathrm{~m}\end{array}$ & \\
\hline & & & $\begin{array}{c}\text { Blank } \\
178.8 \text { to } 179.1 \mathrm{~m} \\
(586.7 \text { to } 587.5 \mathrm{ft})\end{array}$ & & (420 to $430 \mathrm{ft}$ ) & \\
\hline & & & $\begin{array}{c}\text { Slotted } \\
179.1 \text { to } 185.2 \mathrm{~m} \\
(587.5 \text { to } 607.5 \mathrm{ft})\end{array}$ & & \multirow{2}{*}{$\begin{array}{l}\text { Chevereaux gravel } \\
131.1 \text { to } 191.5 \mathrm{ml} \\
(430 \text { to } 628 \mathrm{ft})\end{array}$} & \\
\hline & & & $\begin{array}{c}\text { Bull-nosed tailpipe } \\
185.2 \text { to } 191.5 \mathrm{~m} \\
(607.5 \text { to } 628.3 \mathrm{ft})\end{array}$ & & & \\
\hline
\end{tabular}

a Additional details regarding casing and tubing are provided in Appendix A.3.

Fluid levels after completion. Data on actual static water levels measured during postcompletion activities will be provided in a future report

$c^{\text {Moyno }^{\oplus}}$ stators are composed of carbon steel. 


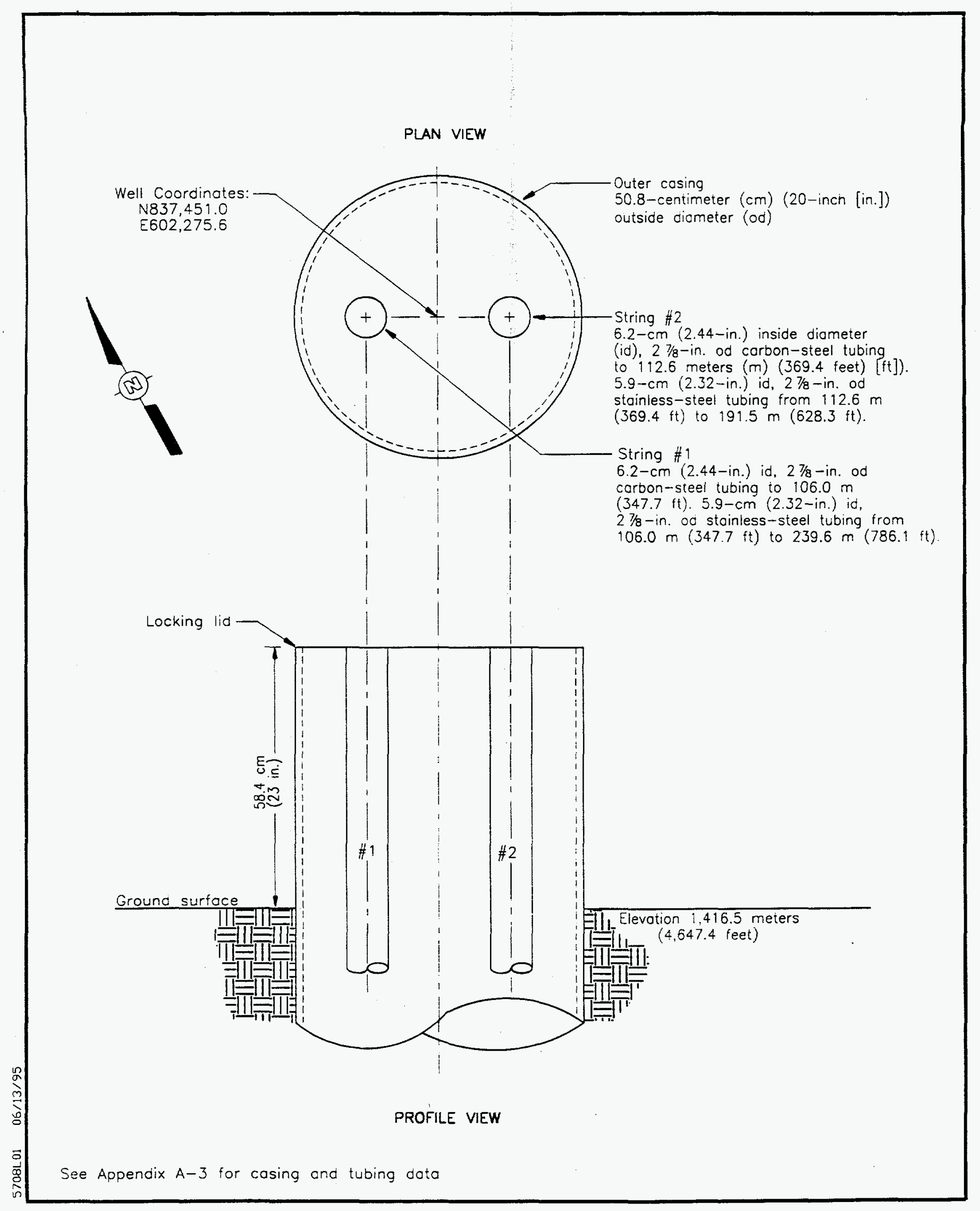

Figure 7-2

Well ER-30-1 Wellhead Diagram 


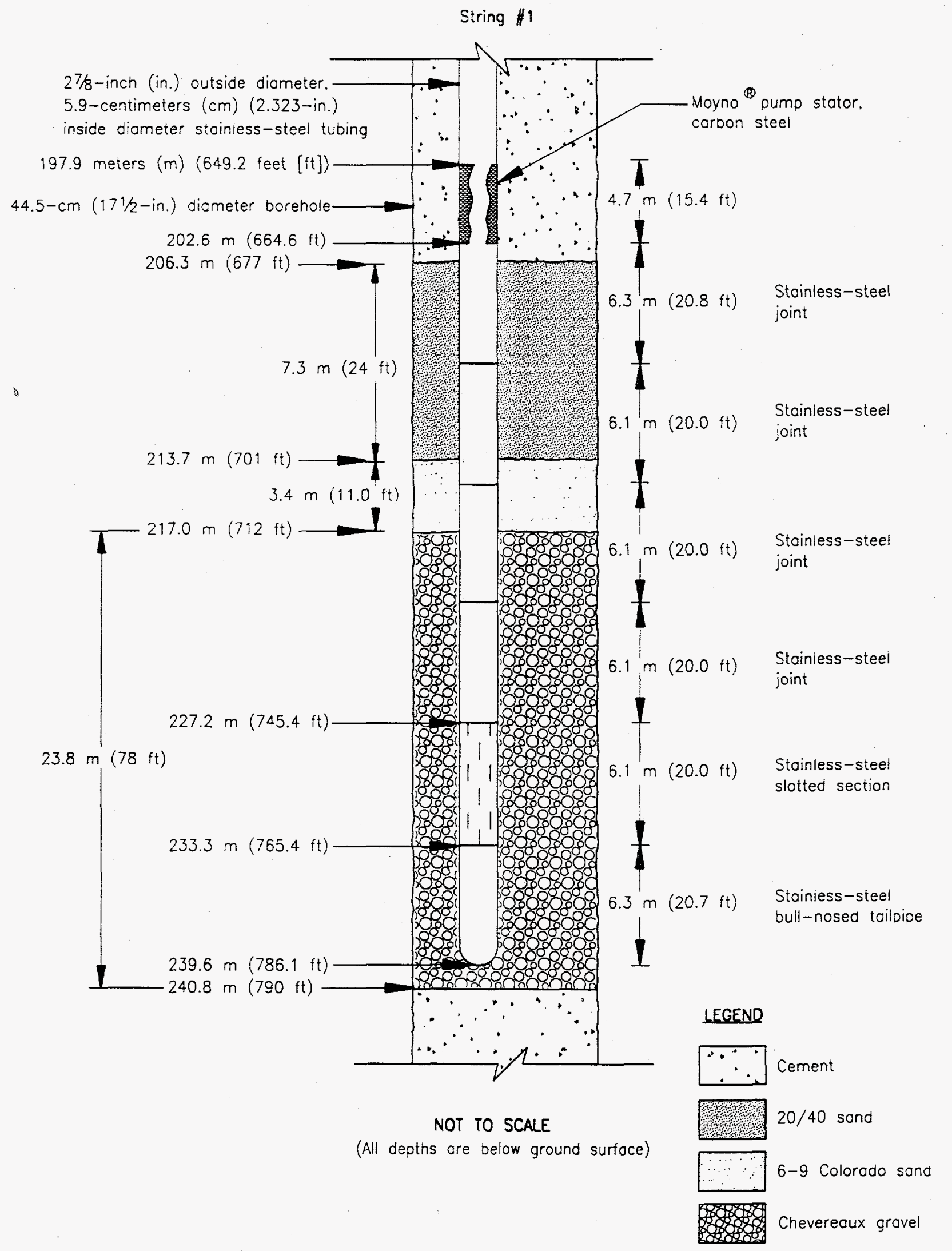

Figure 7-3

Completion Configuration for Well ER-30-1, Lower Completion Zone (String \#1) 


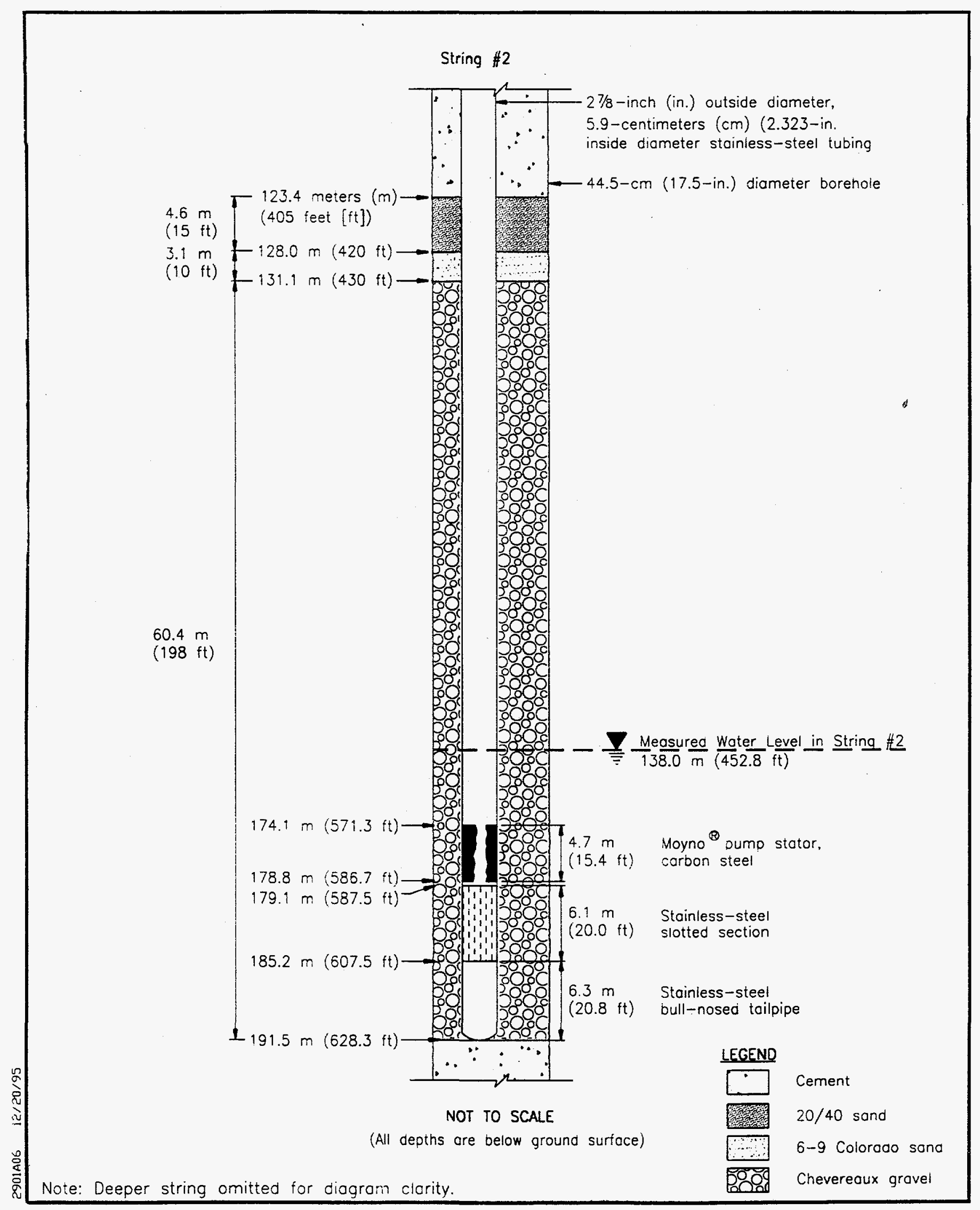

Figure 7-4

Completion Configuration for Well ER-30-1, Upper Completion Zone (String \#2) 


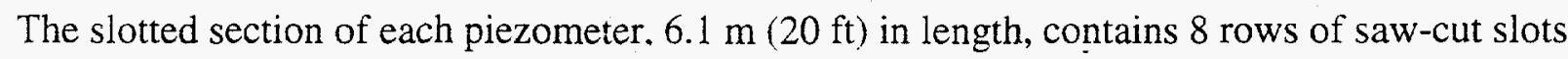
$7.62-\mathrm{cm}$ long and $0.3-\mathrm{cm}$ wide ( $3 \mathrm{in}$. by $0.12 \mathrm{in}$.), staggered on 30.48 -cm (12-in.) centers. The slotted section and the pump stator in String \#1 were separated by four solid joints (blanks) so that the stator could be encased in cement to reduce contact of its carbon-steel case with groundwater and to increase pump stability. In String \#2, the gravel pack extends above the water table to allow for maximum water inflow from this zone; thus, the pump stator was placed just $0.3 \mathrm{~m}(0.8 \mathrm{ft})$ above the slotted section to allow for maximum available drawdown during pumping of the string. Cementing the stator in place was not possible in this configuration.

\subsubsection{Rationale for Differences between Actual and Proposed Well Design}

The well-completion design and the program criteria were specified based on the planned hole depth of $609.6 \mathrm{~m}$ (2,000 ft) (IT, 1994; RSN, 1994a,b). The original program specified that String $\# 1$ be set near the bottom of the well and the depth of String \#2 be determined by the depth of the water table. Borehole conditions forced the completion program to be redesigned, as follows:

- The completion depth of Well ER-30-1 was $321.5 \mathrm{~m}$ (1,055 ft) shallower than desired and, as a result, String \#1 was landed $239.6 \mathrm{~m}$ (786 ft) higher than anticipated. The completion strings were placed $48.2 \mathrm{~m}(158 \mathrm{ft})$ apart instead of $400 \mathrm{~m}(1,310 \mathrm{ft})$ apart.

- In String \#1, the Moyno ${ }^{\circledR}$ pump stator was installed $24.7(81 \mathrm{ft}$ ) above the slotted section instead of $15 \mathrm{~m}(50 \mathrm{ft})$ to permit the pump to be encased in cement to increase pump stability.

- In String \#2, the Moyno ${ }^{\circledR}$ stator was installed $0.3 \mathrm{~m}(0.8 \mathrm{ft})$ above the slotted section instead of $15 \mathrm{~m}(50 \mathrm{ft})$, and the gravel pack was extended above the water table to allow for maximum water inflow from this zone.

Selection of the two intervals in which the piezometers were installed was based on their water production potential, their relative positions within the wellbore, the accessibility of the zones without cleaning fill material, and a desired minimum separation distance between the two piezometer screens.

\subsection{Well Completion Methods}

\subsubsection{Introduction}

The two completion zones in Well ER-30-1 were gravel-packed and then isolated from each other and the rest of the borehole by means of sand and cement barriers. Well-construction materials were inspected in accordance with relevant procedures; standard decontamination procedures were employed to prevent introduction of contaminants into the well. Caliper logs 
were used to calculate the volumes of cement needed during well completion. The Photon Annulus Investigation Log was used to monitor the rise in cement and the placement of sand and gravel.

\subsubsection{Completion Method}

The filter packs for both Strings \#1 and \#2 consisted of Chevereaux gravel, with 6/9 Colorado sand and 20-40 silica sand placed on top to prevent infiltration of cement into the screened interval. As-built measurements for both strings are shown on Figures 7-3 and 7-4.

A "tremie" line consisting of $27 / 8$-in. od Hydril ${ }^{\circledR}$ tubing was tripped into the hole and used for emplacement of all sand, gravel, and cement. The hole was cemented from the top of fill at $285.0 \mathrm{~m}$ ( $935 \mathrm{ft}$ ) to the depth of $240.8 \mathrm{~m}$ (790 ft) using Type II cement with 2-percent calcium chloride $\left(\mathrm{CaCl}_{2}\right)$. String \#1 was landed at $239.6 \mathrm{~m}(786.1 \mathrm{ft})$, and AWS verified the depth of the piezometer by tagging the top of the Moyno ${ }^{\oplus}$ pump stator with a sinker bar. The gravel filter pack and sand barriers were then emplaced, followed by another cement plug to $191.5 \mathrm{~m}(628 \mathrm{ft})$.

String \#2 was landed at $191.5 \mathrm{~m}$ ( $628.3 \mathrm{ft}$ ), and the position of the top of the pump stator was verified by AWS. The gravel filter pack and sand barriers were emplaced, and well construction was completed by cementing the remainder of the hole to the surface. 


\subsection{Actual versus Planned Costs and Scheduling}

The cost summary for Well ER-30-1 (RSN, 1994c) (based on work-order estimates) projected that drilling and completion operations would require 34 days to accomplish. The RSN projection allowed for 26 days of drilling and geophysical logging activities and 8 days of completion operations. Actual time spent drilling and logging Well ER-30-1 was 28 days, while completion required 2 days, for a total of 30 days. Although the TD of Well ER-30-1 was approximately $175 \mathrm{~m}(574 \mathrm{ft})$ shallower than planned, the added drilling time reflects time spent stabilizing the hole (see Section 2.0) and stopping drilling to haul excess water from the drill site (see Section 5.0). The shorter than expected completion time reflects the shorter than projected completion strings.

The planned cost for 26 days of drilling, geophysical logging, and materials was $\$ 685,180$. The planned cost for 8 days of completion and materials was $\$ 418,315$. The total planned cost for Well ER-30-1 was $\$ 1,103,495$.

The actual cost of Well ER-30-1 through completion totaled $\$ 867,088$ or approximately 21 percent less than the planned cost. Table 8-1 provides a comparison of the actual versus predicted costs. Figure $8-1$ is a comparison of the planned versus actual drilling costs, and Figure 8-2 is a comparison of the planned versus actual completion costs. These data (taken from the RSN summary report for Fiscal Year 1994 [RSN, 1994c]) show actual costs plotted against the day the charges were received from REECo, not against actual drilling and completion days. The additional days shown for drilling and completion also reflect subsequent activities related to water-level measurements, preparation of the well for future development and vacating the site.

Table 8-1

Well ER-30-1 Planned versus Actual Costs

\begin{tabular}{|l|c|c|c|}
\hline \multicolumn{1}{|c|}{ Activity } & $\begin{array}{c}\text { Planned } \\
\text { Cost }\end{array}$ & $\begin{array}{c}\text { Actual } \\
\text { Cost }\end{array}$ & $\begin{array}{c}\text { Percent Difference } \\
\text { Actual versus Planned }\end{array}$ \\
\hline \hline Drilling and geophysical logging & $\$ 685,180$ & $\$ 634,000$ & $-8 \%$ \\
\hline Well completion & $\$ 418,315$ & $\$ 233,088$ & $-44 \%$ \\
\hline Total & $\$ 1,103,495$ & $\$ 867,088$ & $-21 \%$ \\
\hline
\end{tabular}




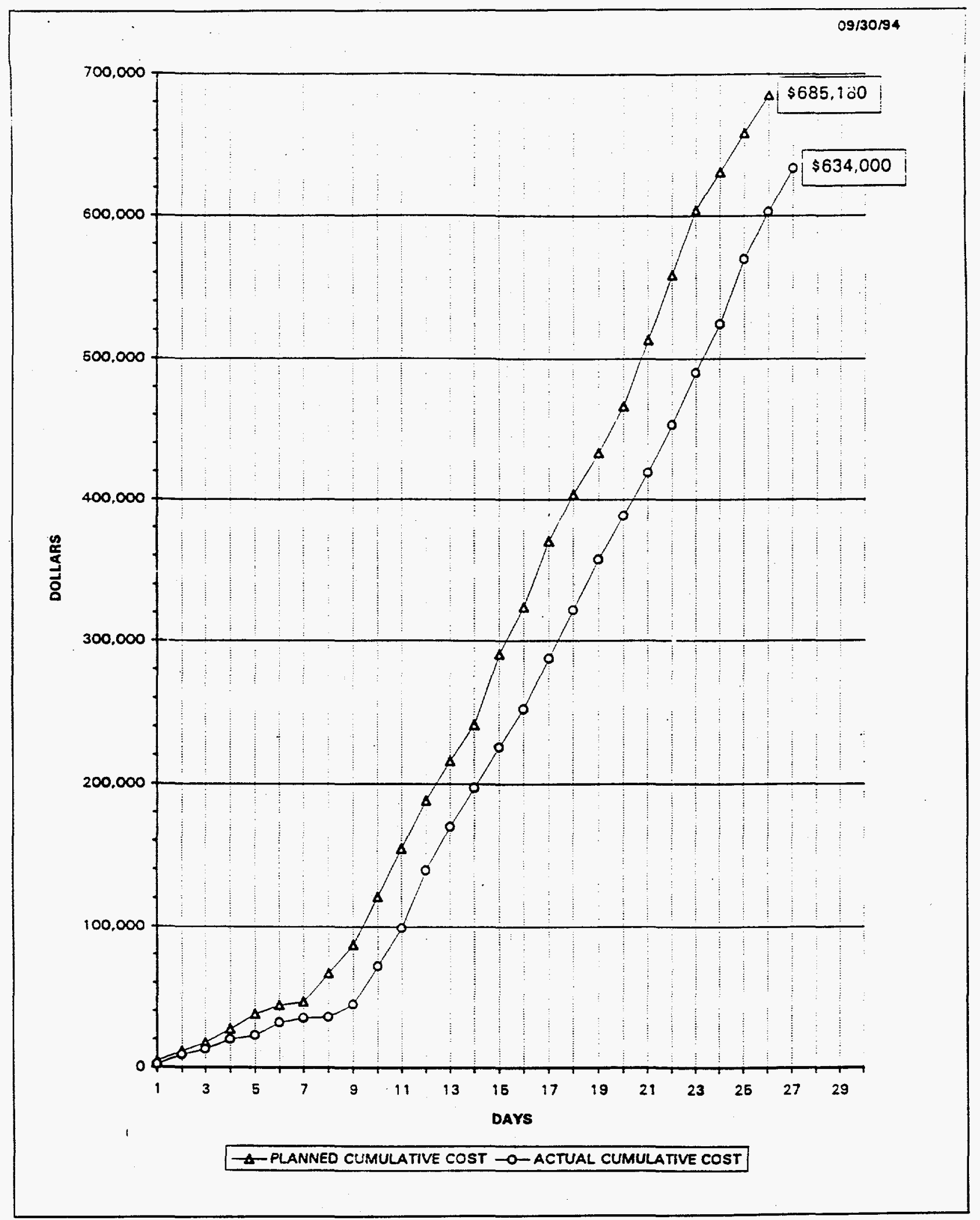

Figure 8-1

Planned versus Actual Costs for Drilling of Well ER-30-1 


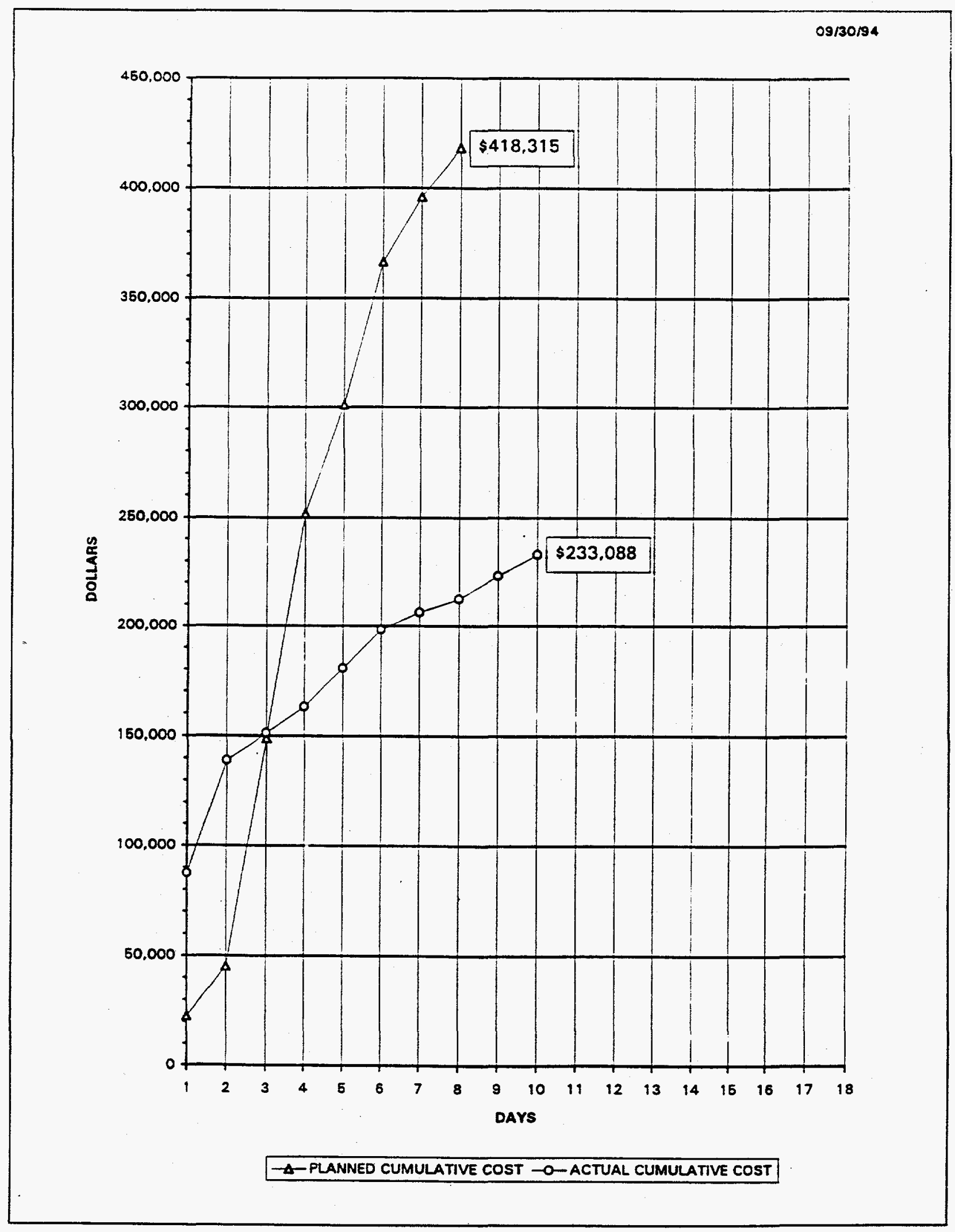

Figure 8-2

Planned versus Actual Costs for Completion of Well ER-30-1 


\subsection{Summary, Recommendations, and Lessons Learned}

\subsection{Summary}

Drilling operations commenced at Well ER-30-1 on February 7. 1994, and concluded on March 21, 1994, after the TD of $434.6 \mathrm{~m}(1,426 \mathrm{ft})$ was reached. Well-completion activities were accomplished on March 24 and 25, 1995. Crews worked on a five-day-per-week, 24-hourper-day schedule, and 30 working days were expended on well-drilling, logging, and completion activities. A ten-day drilling hiatus took place after drilling and setting the surface casing while crews worked another job.

Drilling of Well ER-30-1 took longer than expected because of time required to manage sloughing problems and to haul excess water from the rig site. Water production was first noted

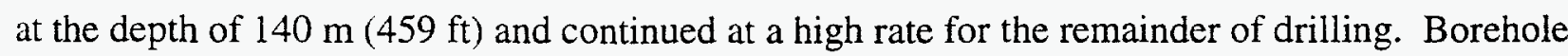
sloughing problems began at the depth of $246.9 \mathrm{~m}(810 \mathrm{ft})$ and required cementing and redrilling. After the second cementing procedure, hole size was reduced from 44.5 to $31.1 \mathrm{~cm}(171 / 2$ to $12 \frac{1}{4}$ in.), and the hole was drilled at the smaller size from 246.9 to $434.6 \mathrm{~m}$ ( 810 to $1,426 \mathrm{ft}$ ). Circulation was lost at that point, and the drilling assembly became stuck. After a day of work to free the bit and two more days of continue sloughing problems during geophysical logging, the drilled depth of $434.6(1,426 \mathrm{ft})$ was determined to be acceptable as TD, approximately $175 \mathrm{~m}$ (574 ft) shallower than planned. The shallower depth was accepted because it was deemed not cost effective to continue drilling in the face of severe sloughing problems and high water

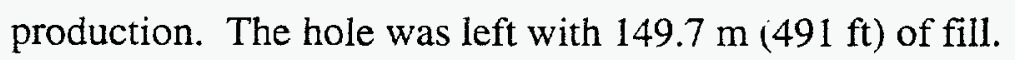

When well-completion activities began, the working depth in the borehole was $285.0 \mathrm{~m}$ (935 $\mathrm{ft}$ ). Precompletion open-hole development was not attempted because of unstable hole conditions. Two piezometers were successfully installed in the borehole, although they were placed higher

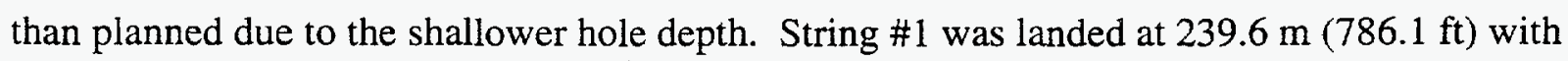
one $6.1-\mathrm{m}(20-\mathrm{ft})$ slotted interval located within gravelly volcanic sediments. String \#2 was landed at $191.5 \mathrm{~m}(628.3 \mathrm{ft})$ to achieve maximum separation from String \#1, but remain well below the static water level. String $\# 2$ has one $6.1-\mathrm{m}(20-\mathrm{ft})$ slotted interval located within a water-producing basalt.

The DRI installed experimental TDR instrumentation in the fluid discharge line as part of a program to develop a method for "real-time" determination of when water is encountered during

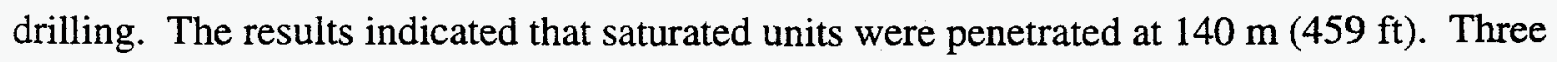




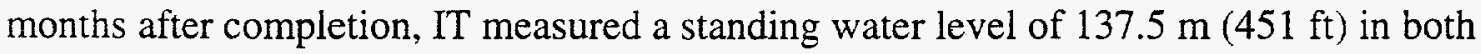
piezometer strings.

Composite drill cuttings were collected continuously from Well ER-30-1 at 3.05-m (10-ft) intervals as drilling progressed from the surface to the TD. Thirteen percussion-gun sidewall core samples were collected at 7 locations in the borehole (sampling was attempted at 11 locations). The 142 cuttings samples and the sidewall core samples are archived at the USGS Core Library in Mercury, Nevada. Geophysical logs were run during drilling to aid in drilling and construction of the well and, after drilling was completed, to aid in verification of the geologic and hydrologic characteristics of the units. Geophysical logs for Well ER-30-1 are filed at RSN in Mercury, Nevada, and at IT, Las Vegas, Nevada.

The total estimated cost for Well ER-30-1 was $\$ 1,103,495$. The actual cost was $\$ 867,088$, which is approximately 21 percent less than the estimated cost.

Because drilling of Well ER-30-1 was stopped approximately $175 \mathrm{~m}(574 \mathrm{ft})$ shallower than planned, less geologic data than desired were obtained from the hole. However, the relatively high water table in this well allowed for shallower completions than originally proposed, and the overall objective of drilling and installing a well to provide hydrologic information for the western part of the NTS has been accomplished.

\subsection{Recommendations for Additional Data Interpretation}

The following paragraphs describe additional work needed to further interpret the geologic, hydrologic, and geophysical data gathered during drilling and completion of Well ER-30-1.

\section{Hydrologic Analyses}

Hole sloughing problems at Well ER-30-1 precluded any open-hole development, but postcompletion development was accomplished in March 1995, and one groundwater characterization sample was collected. Analysis of any subsequent water-level data is necessary to achieve the primary scientific objectives for Well ER-30-1.

\section{Fracture Study}

Analysis of geologic data, geophysical logs, and hydrologic data from Well ER-30-1 could provide insight into the hydrogeologic setting in this area of the NTS. Correlation of fracture characteristics with geophysical log data could make planning logging programs for future UGTA programs more focused, so that perhaps fewer logs could provide more useful data. 


\section{Hydrogeologic Characterization of the Timber Mountain Moat Area}

The Timber Mountain moat is an important, but little understood, part of the hydrogeologic regime in the western NTS. A regional analysis of data from Well ER-30-1 and from nearby holes may be called for at this point to help understand the hydrogeologic implications of the shallow water table and the high volume of water produced at Well ER-30-1.

\subsection{Lessons Learned}

The following paragraphs describe lessons learned during drilling and construction of Well ER-30-1. As appropriate, these lessons can be applied to other UGTA drilling projects.

\section{Drilling Method}

The possibility of using dual-wall reverse-circulation drilling should be explored for future holes drilled in poorly consolidated materials such as alluvium and friable bedded tuff to decrease the likelihood of formation sloughing and related problems.

\section{Drilling Fluid}

The use of air-foam drilling fluid contributed to the successful construction of Well ER-30-1 because it does not leave significant residue in the formation or mudcake on the borehole walls. Also, returns to the surface during drilling are dry, making identification of the onset of groundwater production easier. However, in direct-circulation systems, the use of such a lightweight drilling fluid requires circulating at a high velocity, which can contribute to borehole erosion. Also, the air-foam mixture does not support the formation as well as a higher-viscosity fluid such as drilling mud. Every drilling project must be continuously monitored, and the tradeoffs of successful drilling versus successful well development must be weighed throughout the drilling process.

\section{Hole Sloughing}

The drilling program listed a series of contingencies for dealing with borehole sloughing problems, including cementing and redrilling, and trying different drilling fluids. The setting of intermediate casing was listed as an action item in the program, but was tied to the expectation of penetrating a specific geologic formation, and was not specifically designated as a measure to minimize borehole sloughing. By the time the specified formation was penetrated in Well ER-30-1, it was judged to be too late for an intermediate casing to solve the problem without impacting the successful completion of the well. Perhaps in the future, specifications for intermediate casing should be tied to hole conditions rather than to expected geologic formations, especially where there is little geologic data for prediction of borehole conditions. 


\subsection{References}

Carr, W.J., 1966, Geology and Test Potential of the Timber Mountain Caldera Area, Nevada, U.S. Geological Survey, Technical Letter NTS-174, Washington, DC.

Hokett, S.L., C.E. Russell, and D.R. Gillespie, Desert Research Institute, 1994, Water Level Detection During Drilling Using Time Domain Reflectometry, Las Vegas, NV.

IT Corporation, 1994, Drilling/Completion Criteria for Underground Test Area Remedial Investigation and Feasibility Study ER-30-1, DOE/NV/10972-73, Las Vegas, NV.

Lyles, B.F., D. Gillespie, and J.D. Donithan, Desert Research Institute, 1994, Well Validation: ER-30-1, Las Vegas, NV.

Raytheon Services Nevada, 1995, ER-30-1 Hole History, Las Vegas, NV.

Raytheon Services Nevada, 1994a, Drilling Program for Underground Test Area Remedial Investigation/Feasibility Study (UGTA RI/FS) Well ER-30-1 Surface and Main-Hole Drilling, Work Order \#3753-035, Las Vegas, NV.

Raytheon Services Nevada, 1994b, Completion Program for Underground Test Area Operable Unit (UGTA-OU) Well ER-30-1, Work Order \#3753-035, Las Vegas, NV.

Raytheon Services Nevada, 1994c, "UGTA Rig/Material Cost Summary for Fiscal Year 1994," RSN Internal Memorandum, Las Vegas, NV.

U.S. Department of Energy, Nevada Operations Office, 1994a, Underground Test Area Operable Unit Project Management Plan, DOE/NV-UC-700, Las Vegas, NV.

U.S. Department of Energy, 1994b, Fluid Management Plan for the Underground Test Area Operable Unit, DOE/NV--370, Las Vegas, NV.

Warren, R.G., Los Alamos National Laboratory, 26 July 1994. Letter to F.M. Byers, USGS. 


\section{Appendix A Drilling Data}

A-1 List of Records of Verbal Communication for Well ER-30-1

A-2 Drilling Parameter Log

A-3 Casing and Tubing Data for Well ER-30-1

A-4 Well ER-30-1 Drilling Fluids and Cement Composition 


\section{Appendix A-1}

List of Records of Verbal Communication for Well ER-30-1 
Appendix A-1

Raytheon Services Nevada, Record of Verbal Communications (RVC) Applicable to Well ER-30-1 Drilling and Completion

\begin{tabular}{|c|c|c|}
\hline RVC\# & Date & Subject \\
\hline Unnumbered & $03 / 09 / 94$ & $\begin{array}{l}\text { UGTA Operable Unit Well ER-30-1: Approval to Move } \\
\text { Fluid in Pits (Lawrence to Thompson) }\end{array}$ \\
\hline RVC-0366 & $03 / 09 / 94$ & $\begin{array}{l}\text { Revision to Drilling Program for UGTA Operable Unit } \\
\text { Well ER-30-1: Drilling Program Changes }\end{array}$ \\
\hline RVC-0367 & $03 / 14 / 94$ & $\begin{array}{l}\text { Revision to Drilling Program for UGTA Operable Unit } \\
\text { Well ER-30-1: Program Changes }\end{array}$ \\
\hline RVC-0368 & $03 / 21 / 94$ & UGTA Operable Unit Well ER-30-1: Logging Deletion \\
\hline RVC-0369 & $03 / 17 / 94$ & $\begin{array}{l}\text { UGTA Operable Unit Well ER-30-1: Freepoint and Back- } \\
\text { Off Service Requirement }\end{array}$ \\
\hline RVC-0370 & $03 / 21 / 94$ & $\begin{array}{l}\text { Revision to Drilling Program for UGTA Operable Unit } \\
\text { Well ER-30-1: Total Depth Change }\end{array}$ \\
\hline RVC-0372 & $03 / 22 / 94$ & $\begin{array}{l}\text { UGTA Operable Unit Well ER-30-1: Additional Logging } \\
\text { Requirements }\end{array}$ \\
\hline RVC-0373 & $03 / 23 / 94$ & $\begin{array}{l}\text { UGTA Operable Unit Well ER-30-1: TV Video } \\
\text { Requirement }\end{array}$ \\
\hline RVC-0374 & $03 / 29 / 94$ & $\begin{array}{l}\text { Revision to Completion Program for UGTA Operable } \\
\text { Unit Well ER-30-1: Program Changes }\end{array}$ \\
\hline RVC-400 & $08 / 02 / 94$ & $\begin{array}{l}\text { Workover Rig Guyline Anchors for UGTA Operable Unit } \\
\text { Wells ER-19-1 and ER-30-1 }\end{array}$ \\
\hline RVC-403 & $09 / 13 / 94$ & $\begin{array}{l}\text { Moyno }{ }^{\circledR} \text { Rods/Rotor Installation in UGTA Operable Unit } \\
\text { Well ER-30-1 }\end{array}$ \\
\hline RVC-404 & $09 / 21 / 94$ & Moyno $^{\circledR}$ Work at UGTA Operable Unit Well ER-30-1 \\
\hline
\end{tabular}


Appendix A-2

Drilling Parameter Log 


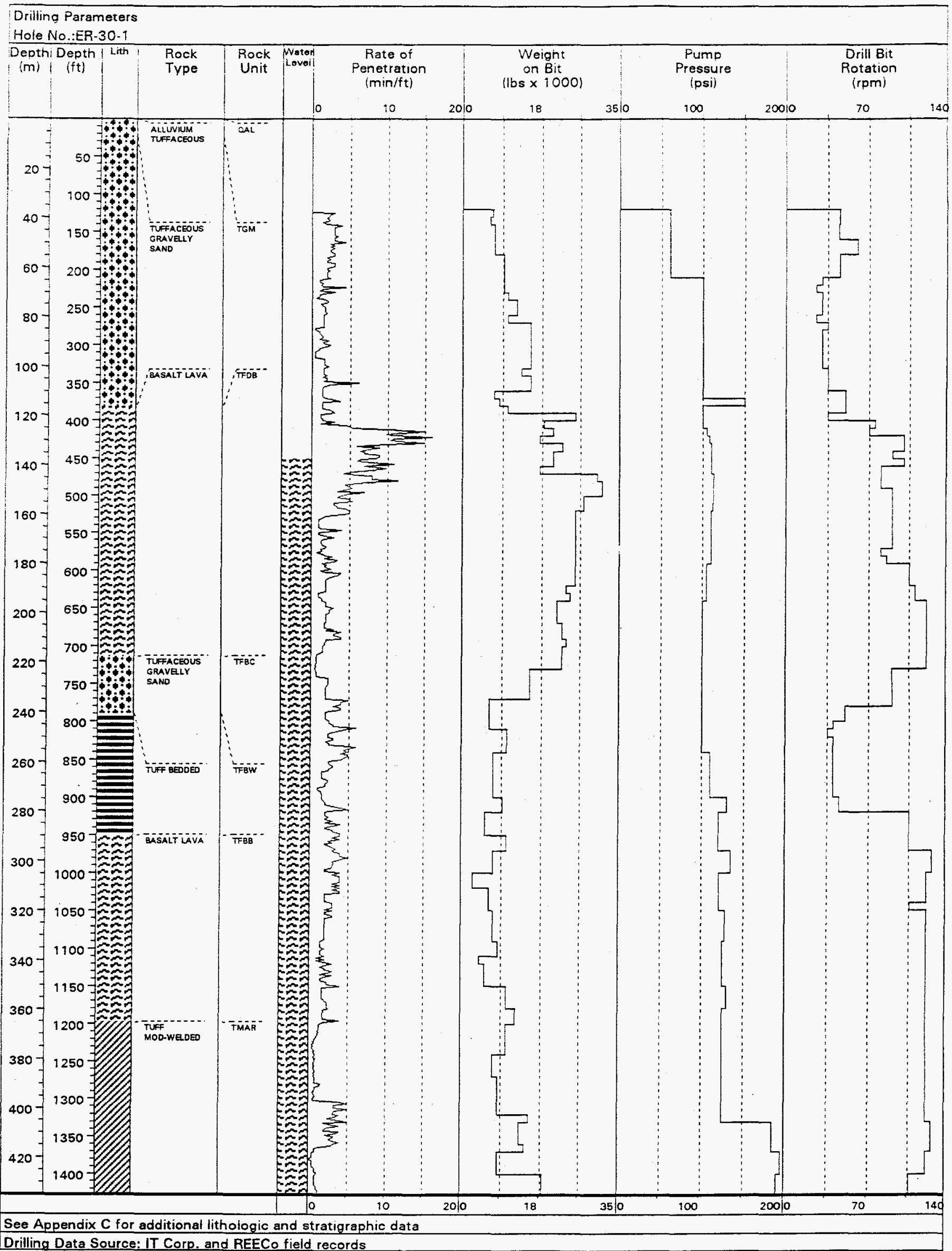




\section{Appendix A-3 \\ Casing and Tubing Data for Well ER-30-1}


Appendix A-3

Casing and Tubing Data for Well ER-30-1

\begin{tabular}{|c|c|c|c|c|c|c|c|}
\hline CASING & $\begin{array}{c}\text { Depth Intervat } \\
\text { meters } \\
\text { (feet) }\end{array}$ & Type & Grade & $\begin{array}{l}\text { Outside } \\
\text { Diameter } \\
\text { (inches) }\end{array}$ & $\begin{array}{c}\text { Inside } \\
\text { Diameter } \\
\text { centimeters } \\
\text { (inches) }\end{array}$ & $\begin{array}{c}\text { Wall } \\
\text { Thickness } \\
\text { centimeters } \\
\text { (inches) }\end{array}$ & $\begin{array}{l}\text { Weight per } \\
\text { foot } \\
\text { (pound/foot) }\end{array}$ \\
\hline $\begin{array}{l}\text { Surface } \\
\text { Casing }\end{array}$ & $\begin{array}{c}0 \text { to } 36.0 \\
(0 \text { to } 118)\end{array}$ & $\begin{array}{c}\text { Carbon } \\
\text { Steel }\end{array}$ & $K-55$ & 20 & $\begin{array}{r}49.5 \\
(19.5) \\
\end{array}$ & $\begin{array}{c}0.64 \\
0.250 \\
\end{array}$ & 52.73 \\
\hline \multicolumn{8}{|l|}{ TUBING } \\
\hline String \#1 & $\begin{array}{l}0 \text { to } 106.0 \\
(0 \text { to } 347.7)\end{array}$ & $\begin{array}{l}\text { Carbon } \\
\text { Steel } \\
\text { Hydril }^{\circ}\end{array}$ & $\begin{array}{c}\text { Range } 2 \\
\mathrm{~N}-80\end{array}$ & $27 / 8$ & $\begin{array}{c}6.2 \\
(2.44)\end{array}$ & $\begin{array}{c}0.55 \\
(0.217)\end{array}$ & 6.5 \\
\hline String \#1 & $\begin{array}{l}106.0 \text { to } 239.6 \\
(347.7 \text { to } 786.1)\end{array}$ & $\begin{array}{l}\text { Stainless } \\
\text { Steel }\end{array}$ & $\begin{array}{c}\text { Schedule } \\
40\end{array}$ & $27 / 8$ & $\begin{array}{c}5.9 \\
(2.31)\end{array}$ & $\begin{array}{c}0.72 \\
(0.283)\end{array}$ & 7.66 \\
\hline String \#2 & $\begin{array}{c}0 \text { to } 112.6 \\
(0 \text { to } 369.4)\end{array}$ & $\begin{array}{l}\text { Carbon } \\
\text { Steel } \\
\text { Hydril }^{*}\end{array}$ & $\begin{array}{c}\text { Range } 2 \\
N-80\end{array}$ & $2^{7} \%$ & $\begin{array}{c}6.2 \\
(2.44)\end{array}$ & $\begin{array}{c}0.55 \\
(0.217)\end{array}$ & 6.5 \\
\hline String \#2 & $\begin{array}{l}112.6 \text { to } 191.5 \\
(369.4 \text { to } 628.3)\end{array}$ & $\begin{array}{l}\text { Stainless } \\
\text { Steel }\end{array}$ & $\begin{array}{c}304 \mathrm{~L} \\
\text { Schedule } \\
40\end{array}$ & $27 / 8$ & $\begin{array}{c}5.9 \\
(2.31)\end{array}$ & $\begin{array}{c}0.72 \\
(0.283)\end{array}$ & 7.66 \\
\hline
\end{tabular}


Appendix A-4

Well ER-30-1 Drilling Fluids and Cement Composition 


\section{Appendix A-4 \\ Well ER-30-1 Drilling Fluids and Cement Composition}

\begin{tabular}{|c|c|c|}
\hline $\begin{array}{c}\text { \#3 Davis Mix } \\
\text { (Air Foam) } \\
\text { cubic meters }\left(\mathrm{m}^{3}\right) \text { (gallons [gal]) } \\
\text { kilograms }(\mathrm{kg}) \text { (pounds [lb]) }\end{array}$ & $\begin{array}{l}\text { \#10 Polymer } \\
\text { (Air Foam) } \\
\text { kg (lb) }\end{array}$ & $\begin{array}{c}\text { Cement } \\
\text { Composition }\end{array}$ \\
\hline $\begin{array}{c}0.22 \mathrm{~m}^{3}(58 \mathrm{gal}) \text { detergent } \\
907 \mathrm{~kg}(2,000 \mathrm{lb}) \text { bentonite } \\
110 \mathrm{~kg}(50 \mathrm{lb}) \text { guar gum }\end{array}$ & $\begin{array}{l}13.6(30) \text { Baroid }^{a} \\
\text { EZ-Mud DP } P^{\oplus} \text { air foam to } \\
\text { suit conditions }\end{array}$ & $\begin{array}{c}\text { Type II Portland cement } \\
\text { with two-percent calcium } \\
\text { chloride }\end{array}$ \\
\hline
\end{tabular}

$a_{E Z-M u d ~} D P^{\oplus}$ is a product of Baroid Drilling Fluids, Inc.

NOTES:

1. Drilling fluid mixtures consist of 19.1 cubic meters (120 barrels) per load.

2. All water used to mix driling fluids for Well ER-30-1 came from Water Well \#8.

3. A concentrated solution of lithium bromide was added to all introduced fluids to make up a final concentration of 20 to 40 milligrams per liter. 
Appendix B

Well ER-30-1 Fluid Management Status Report 


\section{ER FLUID DISPOSITION STATUS REPORTING FORM}

Site Identification:

Site Location:

Site Coordinates:

Well Classification:

IT Project No:
ER-30-1

Area 30 - NTS

N837,450/E602,276

New Shallow Water Level Well

301957.08020000
Report Date:

DOE/NV Project Manager:

IT Project Manager:

IT Site Representative:

IT Waste Coordinator:
$03 / 22 / 94$

S. Lawrence

J. Eberlin

J. Wurtz

L. Cardenas

\begin{tabular}{|c|c|c|c|c|c|c|c|c|c|c|c|c|}
\hline \multirow{2}{*}{$\begin{array}{l}\text { Well Construction } \\
\text { Activity }\end{array}$} & \multicolumn{2}{|c|}{ Activity Duration } & \multirow{2}{*}{$\begin{array}{c}\text { \#Ops. } \\
\text { Days } \\
\text { (A) }\end{array}$} & \multirow{2}{*}{$\begin{array}{c}\text { Well } \\
\text { Depth } \\
\text { (m) }\end{array}$} & \multirow{2}{*}{$\begin{array}{l}\text { Import } \\
\text { Fluid } \\
\left(\mathrm{m}^{3}\right)\end{array}$} & \multicolumn{2}{|c|}{ Lined Sump \#1 $\left(\mathrm{m}^{3}\right)$} & \multicolumn{2}{|c|}{ Infiltration Sump \#2 $\left(\mathrm{m}^{3}\right)$} & \multirow{2}{*}{$\begin{array}{c}\begin{array}{c}\text { Infiltration } \\
\text { Area }\left(\mathrm{m}^{3}\right)\end{array} \\
\text { Liquids }\end{array}$} & \multirow{2}{*}{$\begin{array}{l}\text { Other } \\
\left(\mathrm{m}^{3}\right) \\
\text { (C) }\end{array}$} & \multirow{2}{*}{$\begin{array}{c}\text { Fluid Quality } \\
\text { Objectives } \\
\text { Met? }\end{array}$} \\
\hline & From & To & & & & $\begin{array}{c}\text { Solids } \\
\text { (B) }\end{array}$ & Liquids & Solids & Liquids & & & \\
\hline $\begin{array}{l}\text { Stage I: } \\
\text { Vadose-Zone Drilling }\end{array}$ & $03 / 02 / 94$ & $03 / 04 / 94$ & 3 & $0-197$ & 445 & 26 & 0 & -0 & 478 & (D) & 0 & YES \\
\hline $\begin{array}{l}\text { Stage II: } \\
\text { Saturated-Zone } \\
\text { Drilling }\end{array}$ & $03 / 07 / 94$ & $03 / 21 / 94$ & 11 & $\begin{array}{l}197- \\
435\end{array}$ & 738 & 87 & 240 & -0 & 4,219 & (D) & *826 & YES \\
\hline $\begin{array}{l}\text { Stage III: } \\
\text { Initial Well } \\
\text { Development }\end{array}$ & NA & NA & NA & 285 & NA & NA & NA & NA & NA & (D) & NA & NA \\
\hline $\begin{array}{l}\text { Stage IV: } \\
\text { Aquifer Testing (E) }\end{array}$ & NA & NA & NA & 285 & NA & NA & NA & NA & NA & (D) & NA & NA \\
\hline $\begin{array}{l}\text { Stage V: } \\
\text { Well Completion }\end{array}$ & $03 / 24 / 94$ & $03 / 25 / 94$ & 2 & \multirow{2}{*}{285} & \multirow{2}{*}{ NA } & \multirow{2}{*}{ NA } & \multirow{2}{*}{2,236} & \multirow{2}{*}{ NA } & \multirow{2}{*}{ NA } & \multirow{2}{*}{ (D) } & \multirow{2}{*}{ NA } & \multirow{2}{*}{ YES } \\
\hline Final Development & $\begin{array}{l}06 / 28 / 94 \\
(F)\end{array}$ & $02 / 01 / 95$ & 44 & & & & & & & & & \\
\hline \multicolumn{3}{|c|}{ Cumulative Totals to Date: } & 60 & 285 & 1,183 & 113 & 2,476 & (D) & 4,697 & (D) & 826 & YES \\
\hline \multicolumn{13}{|c|}{$\begin{array}{l}\text { (A) Operational days refer to the number of days that the } \\
\text { (B) Solids volume estimates include calculated added vol } \\
\text { (C) "Other" refers to fluid conveyance to other fluid manag } \\
\text { (D) Optional fluid management devices not installed for th } \\
\text { (E) No aquifer testing planned for this well. } \\
\text { (F) Date that pumping began; installation of equipment to } \\
\text { NA = Not applicable; } m=\text { meters; } \mathrm{m}^{3}=\text { cubic meters. } \\
\text { Total Facility Capacities: Lined Sump } \# 1=2,380 \mathrm{~m}^{3} \\
\text { Remaining Facility Capacity (Approximate) as of } 03 / 22 \\
{ }^{*} 826 \mathrm{~m}^{3} \text { of fluids were transported from Well ER-30-1 infilt }\end{array}$} \\
\hline
\end{tabular}

IT Authorizing Signature/Date: M/ichare al. OKfagan 12.20 .95 
UGTA RI/FS Fluid Management Chemistry

ER-30-1

Anions \& Additional Analytes

\begin{tabular}{|c|c|c|c|c|c|c|c|c|c|}
\hline \multicolumn{5}{|c|}{ Parameter } & $\mathbf{F}$ & $\mathrm{pH}$ & $\mathrm{NO} 2 / \mathrm{NO} 3$ & TDS & TOC \\
\hline \multicolumn{5}{|c|}{ Fluid Quality Objectives $(\mathrm{mg} / \mathrm{L})$} & 20 & $>2 ;<12$ & 100 & $\mathrm{NA}$ & NA \\
\hline Site & Date & Sample ID & Type & Matrix & & & & & \\
\hline ER-30-1 & $03 / 07 / 94$ & GCPO0224 & FMS-DL & Fluid & 1.4 & 8.05 & $\therefore$ & 206 & - \\
\hline ER-30-1 & $03 / 11 / 94$ & GCP00227 & FMS-DL & Fluid & 0.75 & 9.09 & $\therefore$ & 521 & $\therefore$ \\
\hline EP-30-1 & $03 / 21 / 94$ & GCP00230 & FMS-DL & Fluid & 1.3 & 8.42 & $\cdot$ & 510 & $\therefore$ \\
\hline ER-30-1 & $06 / 28 / 94$ & GCP00261 & FMS.DL & Water & 1.6 & - & 1.6 & 360 & - \\
\hline ER-30-1 & $06 / 29 / 94$ & GCP00262 & FMS-DL & GW & 2.1 & - & 19 & 210 & - \\
\hline ER-30-1 & $07 / 05 / 94$ & GCP00263 & FMS-DL & GW & 1.8 & - & 0.41 & 240 & - \\
\hline ER-30-1 & $08 / 02 / 94$ & GCP00264 & FMS-DL. & GW & 1.50 & - & 4.710 & 231 & $\therefore$ \\
\hline ER-30-1 & $08 / 02 / 94$ & GCP00265 & FMS-DL & GW & .1 .53 & - & 4.510 & 224 & - \\
\hline ER-30-1 & $08 / 08 / 94$ & GCP00266 & FMS-DL & GW & 1.4 & - & 5.23 & 249 & $\therefore$ \\
\hline ER-30-1 & $08 / 15 / 94$ & GCP00268 & FMS-DL & $\mathrm{GW}$ & 1.4 & - & 4.52 & 230 & $\therefore$ \\
\hline ER-30-1 & $08 / 15 / 94$ & GCP00269 & FMS-DL & GW & ND & - & 4.52 & 592 & - \\
\hline ER-30-1 & $08 / 22 / 94$ & GCP00281 & FMS-DL & $G W$ & 1.36 & - & 4.97 & 206 & - \\
\hline EA-30-1 & $11 / 04 / 94$ & GCP00283 & FMS-DL & GW & 1.14 & - & 5.88 & - & - \\
\hline ER-30-1 & $11 / 03 / 94$ & GCP00284 & FMS.DL & GW & & $=$ & - & $=$ & ND \\
\hline ER-30-1 & $11 / 03 / 94$ & GCP00284RE & FMS-DL & $\mathrm{GW}$ & - & - & 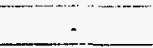 & . & 3.25 \\
\hline ER-30-1 & $11 / 04 / 94$ & GCPO0285 & FMS-DL & GW & - & - & $\therefore$ & - & ND \\
\hline ER-30-1 & $11 / 04 / 94$ & GCP00285RE & FMS.DL & GW & - & - & - & . & 5.55 \\
\hline ER-30-1 & $11 / 21 / 94$ & GCPOO287 & FMS-DL & GW & . & 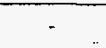 & - & $\because$ & No \\
\hline ER-30-1 & $11 / 22 / 94$ & GCP00288 & FMS-DL & GW & $\therefore$ & $=$ & $\therefore$ & $\therefore$ & ND \\
\hline ER-30-1 & $11 / 23 / 94$ & GCPOO289 & FMS-DL & GW & $\therefore$ & - & $\therefore$ & $\therefore$ & ND \\
\hline ER-30-1 & $11 / 21 / 94$ & GCP00286 & FMS-DL & GW & 1.22 & - & 5.79 & 203 & \\
\hline EF-30-1 & $12 / 06 / 94$ & GCP00290 & FMS-DL & GW & 1.28 & $=$ & 5.79 & 220 & \\
\hline ER-30-1 & $12 / 06 / 94$ & GCP00291 & FMS-DL & GW & - & - & - & - & ND \\
\hline ER-30-1 & $12 / 07 / 94$ & GCP00292 & FMS-DL & GW & - & - & - & - & 2.14 \\
\hline ER-30-1 & $12 / 08 / 94$ & GCP00293 & FMS-DL & GW & - & - &. &. & $\overrightarrow{\mathrm{ND}}$ \\
\hline ER-30-1 & $12 / 09 / 94$ & GCP00294 & FMS-DL & GW & - & - & - & - & ND \\
\hline ER-30-1 & $12 / 13 / 94$ & GCPO0295 & FMS-DL & GW & 1.26 & - & 5.85 & 215 &. \\
\hline ER-30-1 & $12 / 13 / 94$ & GCP00296 & FMS-DL & GW & - & - & - & - & ND \\
\hline ER-30-1 & $01 / 18 / 95$ & GCP00297 & FMS-DL & GW & 1.55 & - & 4.6 & 217 & - \\
\hline ER-30-1 & $01 / 18 / 95$ & GCPOO298 & FMS-DL & GW & - & - & - & - & 1.03 \\
\hline ER-30-1 & $01 / 23 / 95$ & GCP00299 & FMS-DL & GW & 1.31 & - & 6.18 & 129 & - \\
\hline ER-30-1 & $03 / 08 / 94$ & GCPOO226 & FMS-SP & Fluid & 1.4 & 8.24 & - & 412 & - \\
\hline ER-30-1 & $03 / 16 / 94$ & GCP00229 & FMS-SPIDL & Fluid & $<2$ & 11.5 & $\therefore$ & 531 & $\therefore$ \\
\hline ER-30-1 & $03 / 11 / 94$ & GCP00228 & QCS-FR & Water & $<0.10$ & 6.73 & - & 0.8 & - \\
\hline ER-30-1 & $08 / 08 / 94$ & GCP00267 & QCS-FA & Water & ND & - & ND & 24.0 & - \\
\hline ER-30-1 & $08 / 24 / 94$ & GCP00282 & QCS-FR & Water & ND & - & ND & 22.0 & - \\
\hline
\end{tabular}


UGTA RI/FS Fluid Management Chemistry

ER-30-1

\section{Total Metals}

\begin{tabular}{|c|c|c|c|c|c|c|c|c|c|c|c|c|c|c|}
\hline \multicolumn{5}{|c|}{ Parameter } & As & Ba & Cd & $\mathrm{Cr}_{\mathrm{r}}$ & $\mathrm{Hg}$ & $\mathrm{Pb}$ & Se & $\mathrm{Ag}$ & $\mathrm{Cu}$ & $\mathrm{Zn}$ \\
\hline \multicolumn{5}{|c|}{ Fluid Quality Objectives (mg/L) } & 0.5 & 20 & 0.05 & 1.0 & 0.02 & 0.5 & 0.5 & 1.0 & 10 & 50 \\
\hline Site & Date & Sample ID & Type & Matrix & & & & & & & & & & \\
\hline ER-30-1 & $03 / 07 / 94$ & GCP00224 & FMS-DL & Fluid & 0.33 & $\underline{0.14}$ & ND & $<0.016$. & ND & $\leq 0.12$ & $<0.0014$ & ND & 0.016 & 0.082 \\
\hline ER-30-1 & $03 / 11 / 94$ & GCP00227(T) & FMS-DL & Fluid & $<0.14$ & 0.050 & NO & $<0.016$ & ND & ND & $<0.0014$ & ND & 0.015 & 0.029 \\
\hline ER-30-1 & $03 / 11 / 94$ & GCP00227(D) & FMS-DL & Fluid & $<0.14$ & $<0.0060$ & ND & $\mathrm{NO}$ & ND & ND & ND & NO & 0.014 & 0.022 \\
\hline ER-30-1 & $03 / 21 / 94$ & GCP00230 & FMS-DL & Fluid & $<0.14$ & 0.033 & ND & ND & $\mathrm{ND}$ & ND & $<0.0014$ & ND & $<0.0090$ & 0.022 \\
\hline ER-30-1 & $06 / 28 / 94$ & GCP00261(T) & FMS-DL & Water & 0.020 & 0.025 & ND & 0.026 & ND & ND & 0.0026 & ND & - & - \\
\hline ER-30-1 & $06 / 28 / 94$ & GCP00261(D) & FMS-DL & Water & 0.022 & 0.023 & ND & 0.024 & ND & ND & 0.0022 & ND & $\therefore$ & - \\
\hline ER-30-1 & $06 / 29 / 94$ & GCP00262 & FMS-DL & GW & 0.014 & 0.0085 & ND & $<0.016$ & $<0.00043$ & $<0.12$ & ND & ND & - & $\therefore$ \\
\hline ER-30-1 & $07 / 05 / 94$ & GCP00263A & FMS-DL & GW & 0.018 & 0.0093 & ND & $<0.016$ & $\mathrm{ND}$ & ND & $<0.0014$ & NO & $=$ & . \\
\hline ER-30-1 & $07 / 06 / 94$ & GCP00263 & FMS-DL & GW & 0.011 & 0.0063 & ND & $<0.016$ & ND & ND & $N D$ & ND & $\therefore$ & . \\
\hline ER-30-1 & $08 / 02 / 94$ & GCPO0264 & FMS-DL & GW & 0.0109 & ND & ND & ND & ND & 0.0264 & ND & ND & - & $\therefore$ \\
\hline ER-30-1 & $08 / 02 / 94$ & GCP00265 & FMS-DL & GW & 0.0106 & ND & ND & ND & ND & ND & ND & ND & $\therefore$ & $\therefore$ \\
\hline ER-30-1 & $08 / 08 / 94$ & GCP00266 & FMS-DL & GW & ND & ND & ND & ND & ND & ND & ND & ND & - & $\therefore$ \\
\hline ER-30-1 & $08 / 15 / 94$ & GCP00268 & FMS-DL & GW & ND & ND & ND & ND & ND & ND & ND & ND & $=$ & - \\
\hline EA-30-1 & $08 / 15 / 94$ & GCP00269 & FMS-DL & GW & ND & ND & ND & ND & ND & 0.17 & ND & ND & - & $\therefore$ \\
\hline ER-30-1 & $08 / 22 / 94$ & GCP00281 & FMS-DL & GW & ND & ND & ND & ND & ND & ND & ND & ND & $\therefore$ & - \\
\hline ER-30-1 & $11 / 04 / 94$ & GCP00283 & FMS-DL & GW & 0.009 & 0.012 & ND & ND & ND & 0.008 & ND & ND & $\therefore$ & $\therefore$ \\
\hline ER-30-1 & $11 / 21 / 94$ & GCP00286 & FMS-DL & GW & 0.0065 & ND & ND & 0.024 & ND & ND & ND & ND & - & - \\
\hline ER-30-1 & $12 / 06 / 94$ & GCP00290 & FMS-DL & GW & 0.008 & ND & ND & ND & ND & ND & ND & ND & - & - \\
\hline ER-30-1 & $12 / 13 / 94$ & GCP00295 & FMS-DL & GW & 0.009 & ND & $\mathrm{ND}$ & $\mathrm{ND}$ & ND & ND & $\mathrm{ND}$ & ND & $\therefore$ & $\because$ \\
\hline ER-30-1 & $01 / 18 / 95$ & GCP00297 & FMS-DL & GW & 0.012 & ND & ND & 0.043 & ND & 0.004 & NO & $\mathrm{ND}$ & - & \\
\hline ER-30-1 & $01 / 23 / 95$ & GCP00299 & FMS-DL & GW & 0.011 & ND & ND & $\mathrm{ND}$ & ND & 0.018 & NO & ND & $\therefore$ & $\therefore$ \\
\hline ER-30-1 & $03 / 08 / 94$ & GCP00226 & FMS-SP & Fluid & 0.21 & 0.086 & ND & 0.0070 & ND & ND & ND & $\mathrm{ND}$ & 0.013 & 0.048 \\
\hline ER-30-1 & $03 / 16 / 94$ & GCP00229 & FMS-SPIDL & Fluid & 0.44 & 0.27 & ND & 0.049 & 0.00041 & $<0.12$ & $<0,0014$ & ND & 0.024 & 0.11 \\
\hline ER-30-1 & $03 / 11 / 94$ & GCP00228 & QCs.FR & Water & ND & ND & $\mathrm{ND}$ & ND & ND & ND & $<0.0014$ & ND & $<0.0090$ & 0.0094 \\
\hline ER-30-1 & $08 / 08 / 94$ & GCP00267 & QCS-FA & Water & ND & ND & ND & ND & ND & ND & ND & ND & - & . \\
\hline ER-30-1 & $08 / 24 / 94$ & GCP00282 & QCS-FR & Water & ND & ND & ND & ND & ND & ND & ND & ND & & \\
\hline
\end{tabular}


UGTA RI/FS Fluid Management Chemistry ER-30-1

Radiation Chemistry

\begin{tabular}{|c|c|c|c|c|c|c|c|c|c|}
\hline \multicolumn{5}{|c|}{ Parameter } & \multirow{2}{*}{$\frac{\text { Gross }-A}{150}$} & \multirow{2}{*}{$\frac{\text { Uncertainty }}{(+/)}$} & \multirow{2}{*}{$\begin{array}{c}\text { Gross-B } \\
500 \\
\end{array}$} & \multirow{2}{*}{$\begin{array}{c}\text { Uncertainty } \\
(+/)\end{array}$} & \multirow{2}{*}{$\frac{\mathrm{H}^{3}}{\mathrm{pC \textrm {C } / \mathrm { mL }}}$} \\
\hline Fluid Qus & bjectives & $(\mathrm{pCi} / \mathrm{L})$ & & & & & & & \\
\hline Site & Date & Sample ID & Type & Matrix & & & & & \\
\hline ER-30-1 & $03 / 07 / 94$ & GCP00224 & FMS-DL & Fluid (EEAF) & 64.4 & 20.6 & $\therefore$ & $\therefore$ & \\
\hline ER-30-1 & $03 / 07 / 94$ & GCPO0224 & FMS-DL & Fluid (900) & - & - & 76.5 & 12.6 & - \\
\hline ER-30-1 & $03 / 11 / 94$ & GCP00227 & FMS-DL & Fluid & 1.23 & 2.14 & $(-) 0.94$ & 5.93 & - \\
\hline ER-30-1 & $03 / 16 / 94$ & GCP00229A & FMS-DL & Fluid (EERF) & 3.37 & 0.93 & - & - & $\therefore$ \\
\hline ER-30-1 & $03 / 16 / 94$ & GCP00229A & FMS-DL & Fluid (900) & - & - & 4.64 & 1.31 & - \\
\hline & & & & & & & & & $\ldots$ \\
\hline ER-30-1 & $03 / 21 / 94$ & GCP00230 & FMS-DL & Fluid (EERF) & 2.41 & 0.78 & - & $\therefore$ & - \\
\hline ER-30-1 & $03 / 21 / 94$ & GCP00230 & FMS-DL & Fluid $(900)$ & - & - & 5.54 & 1.34 & - \\
\hline ER-30-1 & $06 / 28 / 94$ & GCP00261 & FMS-DL & Water (EERF) & 0.789 & 1.1 & - & 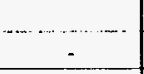 & 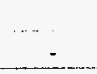 \\
\hline EA-30-1 & $06 / 28 / 94$ & GCP00261 & FMS-DL & Water (900) & - & - & 4.22 & 1.4 & $\therefore$ \\
\hline ER-30-1 & $06 / 29 / 94$ & GCPO0262 & FMS-DL & GW (EERF) & 1.15 & 0.64 & . & - &. \\
\hline ER-30-1 & $06 / 29 / 94$ & GCP00262 & FMS-DL & GW (900) & - & - & 1.99 & 1.3 & $=$ \\
\hline & & & & & & & & & \\
\hline ER-30-1 & $07 / 05 / 94$ & GCP00263 & FMS-DL & GW (EERF) & 0.632 & 0.68 & 3.37 & 1.3 & 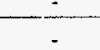 \\
\hline ER-30-1 & $07 / 05 / 94$ & GCPO0263 & FMS-DL & GW $(900)$ & $\cdot$ & - & & & \\
\hline ER-30-1 & $08 / 02 / 94$ & GCP00264 & FMS-DL & GW (900) & 24.7 & 3.0 & 6.59 & 0.88 & - \\
\hline ER-30-1 & $08 / 02 / 94$ & GCP00265 & FMS-DL & GW $(900)$ & 5.58 & 1.12 & 2.70 & 0.55 & - \\
\hline ER-30-1 & $08 / 04 / 94$ & GCPO0258 & FMS-DL & GW & . & - & $\cdots$ & . & $(-) 90$ \\
\hline ER-30-1 & $08 / 12 / 94$ & GCP00266 & FMS-DL & GW $(900)$ & 2.82 & 1.55 & 1.09 & 0.88 & - \\
\hline ER-30-1 & $08 / 15 / 94$ & GCP00268 & FMS-DL & GW $(900)$ & 2.94 & 1.33 & 1.66 & 0.95 & - \\
\hline ER-30-1 & $08 / 15 / 94$ & GCP00269 & FMS-DL & GW (900) & 4.21 & 1.77 & 1.80 & 0.93 & - \\
\hline ER-30-1 & $08 / 15 / 94$ & GCPOD270 & FMS-DL & GW & $\therefore$ & & $\therefore$ & - & $(-) 107$ \\
\hline ER-30-1 & $08 / 22 / 94$ & GCP00281 & FMS-DL & $\mathrm{GW}(900)$ & 3.69 & 0.79 & 2.13 & 0.45 & - \\
\hline ER-30-1 & $11 / 04 / 94$ & GCP00283 & FMS-DL & GW $(900)$ & 5.96 & 2.48 & 1.18 & 1.15 & 67 \\
\hline ER-30-1 & $11 / 21 / 94$ & GCP00286 & FMS-DL & $G W(900)$ & 9.29 & 2.65 & 117 & 12 & $\therefore$ \\
\hline ER-30-1 & $12 / 06 / 94$ & GCPO0290 & FMS-DL & GW (900) & 3.17 & 1.57 & 1.52 & 0.95 & - \\
\hline ER-30-1 & $12 / 13 / 94$ & GCP00295 & FMS-DL & GW $(900)$ & $(-) 0.20$ & 1.80 & 0.12 & 1.28 & $\therefore$ \\
\hline ER-30-1 & $01 / 18 / 95$ & GCP00297 & FMS-DL & GW $(900)$ & 3.41 & 0.73 & 2.21 & 0.55 & - \\
\hline ER-30-1 & $01 / 23 / 95$ & GCP00299 & FMS-DL & GW (900) & 3.37 & 0.76 & 0.97 & 0.44 & $\therefore$ \\
\hline ER-30-1 & $03 / 08 / 94$ & GCP00226 & FMS-SP & Fluid (EERF) & 2.50 & 0.77 & & - & - \\
\hline ER-30-1 & $03 / 08 / 94$ & GCP00226 & FMS-SP & Fluid (900) & - & - & 1.83 & 1.23 & . \\
\hline ER-30-1 & $03 / 17 / 94$ & GCP00229B & FMS-SP & Fluid (EERF) & 0.14 & 0.48 & . & & . \\
\hline
\end{tabular}


UGTA RI/FS Fluid Management Chemistry

\section{ER-30-1}

Radiation Chemistry

\begin{tabular}{|c|c|c|c|c|c|c|c|c|c|}
\hline \multicolumn{5}{|c|}{ Parameter } & Gross-A & Uncertainty & Gross-B & Uncertainty & $\mathrm{H} 3$ \\
\hline \multicolumn{5}{|c|}{ Fluid Quality Objectives (pCi/L) } & 150 & $(+1-)$ & 500 & $(+1-1)$ & $\mathrm{pCl} / \mathrm{mL}$ \\
\hline Site & Date & Sample ID & Type & Matrix & & & & & \\
\hline ER-30-1 & $03 / 17 / 94$ & GCP00229B & FMS-SP & Fluid $(900)$ & - & - & 6.28 & 1.35 & - \\
\hline ER-30-1 & $03 / 07 / 94$ & GCP00225 & QCS-DL & Fluid & ? & - & - & . & $59.7 \mathrm{pCi} / \mathrm{L}$ \\
\hline ER-30-1 & $03 / 21 / 94$ & GCP00231 & OCS-DL & Fluid & - & - & - & - & $(-) 347 \mathrm{pCi} / \mathrm{L}$ \\
\hline & & & & & & & & & \\
\hline ER-30-1 & $03 / 11 / 94$ & GCP00228 & OCS-FA & Water (EERF) & 1.24 & 0.62 & - & - & - \\
\hline ER-30-1 & $03 / 11 / 94$ & GCP00228 & QCS-FR & Water $(900)$ & - & 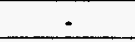 & 1.17 & 1.09 & - \\
\hline ER-30-1 & $08 / 08 / 94$ & GCP0D267 & QCs.FA & Water $(900)$ & $(-) 0.17$ & 0.42 & 0.10 & 0.99 & - \\
\hline ER-30-1 & $08 / 24 / 94$ & GCPO0282 & QCS-FR & Water $(900)$ & $(-) 0.06$ & 0.14 & $(-) 0.69$ & 0.35 & \\
\hline
\end{tabular}




\section{Appendix C \\ Stratigraphic and Lithologic Logs of Well ER-30-1}




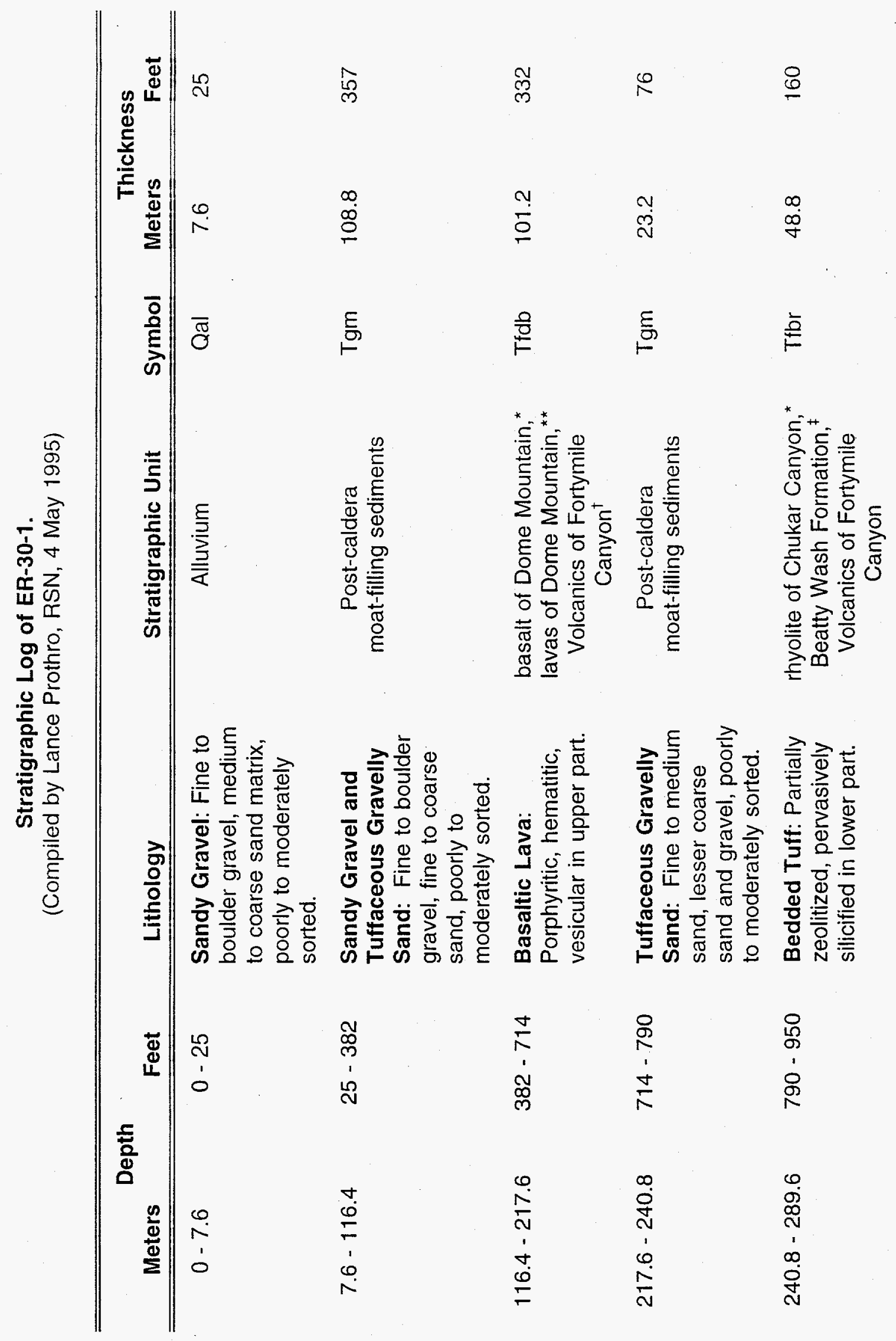


Stratigraphic Log of ER-30-1 (cont.)

\begin{tabular}{|c|c|c|c|c|c|c|}
\hline \multicolumn{2}{|c|}{ Depth } & \multirow[b]{2}{*}{ Lithology } & \multirow[b]{2}{*}{ Stratigraphic Unit } & \multirow[b]{2}{*}{ Symbol } & \multicolumn{2}{|c|}{ Thickness } \\
\hline Meters & Feet & & & & Meters & Feet \\
\hline $289.6-365.2$ & $950-1198$ & $\begin{array}{l}\text { Basaltic Lava: Aphyric, } \\
\text { weakly vesicular, } \\
\text { hematitic. }\end{array}$ & $\begin{array}{c}\text { basalt of Chukar Canyon, }{ }^{*} \\
\text { Beatty Wash Formation, } \\
\text { Volcanics of Fortymile } \\
\text { Canyon }\end{array}$ & Tfbb & 75.6 & 248 \\
\hline $\begin{array}{c}365.2-434.6 \\
\text { TD }\end{array}$ & $\begin{array}{c}1198-1426 \\
\text { TD }\end{array}$ & $\begin{array}{l}\text { Ash-Flow Tuff: } \\
\text { Moderately welded, } \\
\text { devitrified. }\end{array}$ & $\begin{array}{c}\text { mafic-rich } \\
\text { Ammonia Tanks Tuff, }{ }^{*} \\
\text { Ammonia Tanks Tuff, } \\
\text { Timber Mountain Group }{ }^{\dagger}\end{array}$ & Tmar & $>69.5$ & $>228$ \\
\hline
\end{tabular}

ஸ́

*informal member; ${ }^{\star *}$ informal formation; †formal group; ${ }^{\ddagger}$ formal formation 


\section{Lithologic Log of ER-30-1}

(Compiled by Lance Prothro, RSN, 4 May 1995)

Unless otherwise noted, the following descriptions refer to washed cuttings samples at $3.05 \mathrm{~m}$ (10 ft) intervals. The lithologic descriptions follow RSN Department Procedure NTS-GEO-003 and were compiled using the IT Corp. field sample descriptions. In addition. petrographic analysis, quantitative XRD analysis, and descriptions for selected samples provided by R. G. Warren (LANL) were aiso used. Stratigraphic contacts and lithologic divisions are tied to geophysical logs whenever possible.

\begin{tabular}{ccc}
\hline $\begin{array}{c}\text { Depth } \\
\text { Meters/(Feet) }\end{array}$ & Lithologic Description & Stratigraphic Unit \\
\hline
\end{tabular}

$0-7.6 \mathrm{~m}$
$(0-25 \mathrm{ft})$
Sandy Gravel: Pale-yellowish-brown to moderate-yellowish-brown; poorly consolidated; moderately calcareous; fine to boulder gravel in a medium to coarse sand matrix. Gravel consists of welded tuff and rhyolite lava clasts. Sand matrix is very tuffaceous, vitric to partially zeolitized/argillized, moderately sorted, subangular to subrounded, and is composed of quartz and feldspar crystals, tuffaceous rock fragments and fine ash. Interval designation and description are based partly on outcrop data.

$7.6-67.7 m$ $(25-222 \mathrm{ft})$
Sandy Gravel: Pale-yellowish-brown to moderate-yellowish-brown; poorly to moderately consolidated; weakly to moderately calcareous; mostly fine to boulder gravel in a fine to coarse sand matrix. Gravel consists of welded tuff and rhyolite lava clasts. Sand matrix is very tuffaceous, vitric to partially zeolitized/argillized, moderately sorted, subangular to subrounded, and is composed of quartz and feldspar crystals, welded tuff and rhyolitic lava fragments, and
Post-caldera moatfilling sediments 


\begin{tabular}{|c|c|c|}
\hline $\begin{array}{c}\text { Depth } \\
\text { Meters/(Feet) }\end{array}$ & Lithologic Description & Stratigraphic Unit \\
\hline $\begin{array}{c}7.6-67.7 \mathrm{~m} \\
(25-222 \mathrm{ft}) \\
\text { (cont.) }\end{array}$ & $\begin{array}{l}\text { fine ash. Samples contain a variety } \\
\text { of tuffaceous fragments indicating the } \\
\text { presence of interbedded tuffaceous } \\
\text { sands, air-fall ash deposits, and low } \\
\text { volume ash-flow tuff deposits. } \\
\text { Interval designation and description } \\
\text { are based partly on outcrop data. }\end{array}$ & $\begin{array}{l}\text { Post-caldera moat- } \\
\text { filling sediments }\end{array}$ \\
\hline $\begin{array}{l}67.7-116.4 \mathrm{~m} \\
(222-382 \mathrm{ft})\end{array}$ & $\begin{array}{l}\text { Tuffaceous Gravelly Sand: } \\
\text { Moderate-yellowish-brown; } \\
\text { moderately consolidated; weakly to } \\
\text { moderately calcareous; fine to } \\
\text { medium sand with lesser coarse sand } \\
\text { and gravel. Sand is very tuffaceous, } \\
\text { vitric to partially zeolitized/argillized, } \\
\text { poorly to moderately sorted, } \\
\text { subangular to subrounded, and is } \\
\text { composed of feldspar and quartz } \\
\text { crystals, welded tuff and rhyolitic lava } \\
\text { clasts, and fine ash. Coarser sand } \\
\text { and gravel are composed of welded } \\
\text { tuff, rhyolitic lava, and pumice clasts. } \\
\text { Samples contain a variety of } \\
\text { tuffaceous fragments indicating the } \\
\text { presence of interbedded tuffaceous } \\
\text { sands, air-fall ash deposits, and low } \\
\text { volume ash-flow tuff deposits. }\end{array}$ & $\begin{array}{l}\text { Post-caldera moat- } \\
\text { filling sediments }\end{array}$ \\
\hline
\end{tabular}




\begin{tabular}{ccc}
\hline $\begin{array}{c}\text { Depth } \\
\text { Meters/(Feet) }\end{array}$ & Lithologic Description & Stratigraphic Unit \\
\hline
\end{tabular}

$116.4-125.0 \mathrm{~m}$ $(382-410 \mathrm{ft})$

$125.0-217.6 \mathrm{~m}$ $(410-714 \mathrm{ft})$

$217.6-240.8 m$ $(714-790 \mathrm{ft})$
Basaltic Lava: Dark-reddish-brown to very-dusky-red; porphyritic; vesicular with vesicle linings and amygdules of quartz and lesser zeolitic/argillic material; hematitic; rare feldspar phenocrysts. Percussion gun sidewall core sample

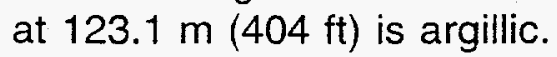

Basaltic Lava: Very-dusky-red and brownish-black; porphyritic; hematitic; minor phenocrysts of feldspar; minor phenocrysts of olivine. White to moderate-yellow zeolite/clay occurs as feldspar replacement and coatings from approximately $182.9-198.1 \mathrm{~m}$ $(600-650 \mathrm{ft})$. Veinlets of zeolite/clay occur from approximately 192.0 $198.1 \mathrm{~m}(630-650 \mathrm{ft})$.

Tuffaceous Gravelly Sand: Moderate-yellowish-brown; moderately consolidated; weakly to moderately calcareous; fine to medium sand with lesser coarse sand and gravel. Sand is very tuffaceous, vitric to partially zeolitized/argillized, poorly to moderately sorted, subangular to subrounded, and is composed of feldspar and quartz crystals, welded tuff and rhyolitic lava clasts, and fine ash. Coarser sand and gravel is composed of welded tuff, rhyolitic lava, and pumice clasts. Samples contain a variety of tuffaceous fragments indicating the basalt of

Dome Mountain, lavas of Dome Mountain, Volcanics of Fortymile Canyon

basalt of Dome Mountain, lavas of Dome Mountain, Volcanics of Fortymile Canyon

Post-caldera moatfilling sediments

\section{C-5}




\begin{tabular}{ccc}
\hline $\begin{array}{c}\text { Depth } \\
\text { Meters/(Feet) }\end{array}$ & Lithologic Description & Stratigraphic Unit \\
\hline
\end{tabular}

\author{
$217.6-240.8 \mathrm{~m}$ \\ $(714-790 \mathrm{ft})$ \\ (cont.) \\ $240.8-250.5 \mathrm{~m}$ \\ $(790-822 \mathrm{ft})$
}

$250.5-289.6 \mathrm{~m}$ $(822-950 \mathrm{ft})$ presence of interbedded tuffaceous sands, air-fall ash deposits, and low volume ash-flow tuff deposits.

Bedded Tuff: Dusky-yellow; mostly zeolitized, partially vitric; laminated fine to very fine grained ash deposits; common feldspar and quartz; minor biotite; rare pale-reddish-brown lithic fragments; scarce light-brown (5YR $5 / 6)$ staining.

Bedded Tuff: Very-pale-orange and white to pinkish-gray; mostly zeolitized, partially vitric, becoming pervasively silicified below approximately $262.1 \mathrm{~m}$ (860 ft); fine to coarse grained ash deposits; conspicuous white pumice up to 5 $\mathrm{mm}$ to a depth of approximately $262.1 \mathrm{~m}(860 \mathrm{ft})$; rare to common feldspar with conspicuously large crystals up to $3 \mathrm{~mm}$; rare to minor mafic minerals of biotite and lesser clinopyroxene; conspicuous sphene. Silicification is approximately parallel to bedding creating a color banded appearance in silicified fragments.
Post-caldera moatfilling sediments

rhyolite of Chukar Canyon, Beatty Wash Formation, Volcanics of Fortymile Canyon

rhyolite of Chukar Canyon, Beatty Wash Formation, Volcanics of Fortymile Canyon 
Lithologic Log of ER-30-1 (cont.)

\begin{tabular}{|c|c|c|}
\hline $\begin{array}{c}\text { Depth } \\
\text { Meters/(Feet) }\end{array}$ & Lithologic Description & Stratigraphic Unit \\
\hline $\begin{array}{l}289.6-365.2 \mathrm{~m} \\
(950-1198 \mathrm{ft})\end{array}$ & $\begin{array}{l}\text { Basaltic Lava: Dark-reddish-brown } \\
\text { and very-dusky-red, moderate- } \\
\text { reddish-brown from approximately } \\
350.5-356.6 \mathrm{~m} \text { ( } 1150-1170 \mathrm{ft}) ; \\
\text { aphyric; weakly vesicular with rare } \\
\text { amygdules and coatings of yellow- } \\
\text { green zeolite/clay; hematitic, weakly } \\
\text { calcareous and argillic; minor to } \\
\text { common lath-shaped plagioclase } \\
\text { crystals visible under high } \\
\text { magnification from approximately } \\
350.5-356.6 \mathrm{~m}(1150-1170 \mathrm{ft}) \text {. }\end{array}$ & $\begin{array}{c}\text { basalt of } \\
\text { Chukar Canyon, } \\
\text { Beatty Wash } \\
\text { Formation, } \\
\text { Volcanics of } \\
\text { Fortymile Canyon }\end{array}$ \\
\hline $\begin{array}{c}365.2-434.6 \mathrm{~m} \\
(1198-1426 \mathrm{ft}) \\
\text { TD }\end{array}$ & $\begin{array}{l}\text { Moderately Welded Ash-Flow Tuff: } \\
\text { Moderate-reddish-brown; devitrified; } \\
\text { common grayish-orange-pink pumice; } \\
\text { common felsic phenocrysts of } \\
\text { feldspar and quartz; common biotite. } \\
\text { Samples are heavily contaminated } \\
\text { with lithologies from higher in the } \\
\text { hole. }\end{array}$ & $\begin{array}{c}\text { mafic-rich } \\
\text { Ammonia Tanks Tuff, } \\
\text { Ammonia Tanks Tuff, } \\
\text { Timber Mountain } \\
\text { Group }\end{array}$ \\
\hline
\end{tabular}


Appendix D

Geophysical Logs 
Appendix D contains presentations of geophysical logs run at Well ER-30-1. Table D-1, Geophysical Log Summary, summarizes the logs presented. See Table 3-1 for more information on logs run in Well ER-30-1.

\section{Table D-1 \\ Geophysical Log Summary}

\begin{tabular}{|c|c|c|c|c|}
\hline Log Type & $\begin{array}{l}\text { Log Interval } \\
\text { meters (feet) }\end{array}$ & Run \# & Run Date & $\begin{array}{l}\text { Sample Interval } \\
\text { meters (feet) }\end{array}$ \\
\hline Caliper & $\begin{array}{l}15.2 \text { to } 381.9 \\
(50 \text { to } 1,253)\end{array}$ & CA6-5 & $03 / 18 / 94$ & $N A^{a}$ \\
\hline Density & $\begin{array}{l}28.7 \text { to } 289.0 \\
(94 \text { to } 948)\end{array}$ & CDL-1 & $03 / 21 / 94$ & NA \\
\hline $\begin{array}{l}\text { Epithermal Neutron } \\
\text { Porosity }\end{array}$ & $\begin{array}{c}21.0 \text { to } 250.6 \\
(69 \text { to } 822) \\
210.3 \text { to } 285.0 \\
(690 \text { to } 935)\end{array}$ & $\begin{array}{l}\text { ENP-1 } \\
\text { ENP-2 }\end{array}$ & $\begin{array}{l}03 / 22 / 94 \\
03 / 22 / 94\end{array}$ & $\begin{array}{l}\text { NA } \\
\text { NA }\end{array}$ \\
\hline Acoustic & $\begin{array}{c}140.2 \text { to } 284.7 \\
(460 \text { to } 934)\end{array}$ & $A C-1$ & $03 / 21 / 94$ & NA \\
\hline $\begin{array}{l}\text { Spectral Gamma } \\
\text { Ray }\end{array}$ & $\begin{array}{l}30.5 \text { to } 381.0 \\
(100 \text { to } 1,250)\end{array}$ & SGR-1 & $03 / 18 / 94$ & $\begin{array}{l}0.304 \\
(1.00)\end{array}$ \\
\hline Induction & $\begin{array}{l}31.1 \text { to } 289.0 \\
\text { (102 to } 948)\end{array}$ & DIFL-1 & $03 / 21 / 94$ & $\begin{array}{l}0.304 \\
(1.00)\end{array}$ \\
\hline Dual Lateral & $\begin{array}{c}129.5 \text { to } 285.9 \\
(425 \text { to } 938)\end{array}$ & DLL-1 & $03 / 22 / 94$ & $\begin{array}{l}0.304 \\
(1.00)\end{array}$ \\
\hline $\begin{array}{l}\text { Spontaneous } \\
\text { Potential }\end{array}$ & $\begin{array}{l}129.5 \text { to } 285.9 \\
(425 \text { to } 938)\end{array}$ & DLL-1 & $03 / 22 / 94$ & $\begin{array}{l}0.304 \\
(1.00)\end{array}$ \\
\hline $\begin{array}{l}\text { Total Magnetic } \\
\text { Intensity }\end{array}$ & $\begin{array}{l}36.0 \text { to } 288.0 \\
(118 \text { to } 945)\end{array}$ & MPP-1 & $03 / 22 / 94$ & NA \\
\hline Gamma Ray & $\begin{array}{l}15.2 \text { to } 381.9 \\
(50 \text { to } 1,253)\end{array}$ & GR-5 & $03 / 18 / 94$ & $\begin{array}{l}0.304 \\
(1.00)\end{array}$ \\
\hline Temperature & $\begin{array}{l}26.8 \text { to } 383.4 \\
(88 \text { to } 1,258)\end{array}$ & TL-1 & $03 / 18 / 94$ & $\begin{array}{l}0.304 \\
(1.00)\end{array}$ \\
\hline
\end{tabular}

${ }_{\text {N Not applicable }}$

Epithermal Neutron Porosity is presented as composite log. Run ENP-2 composited at $251 \mathrm{~m}(222 \mathrm{ft})$. 


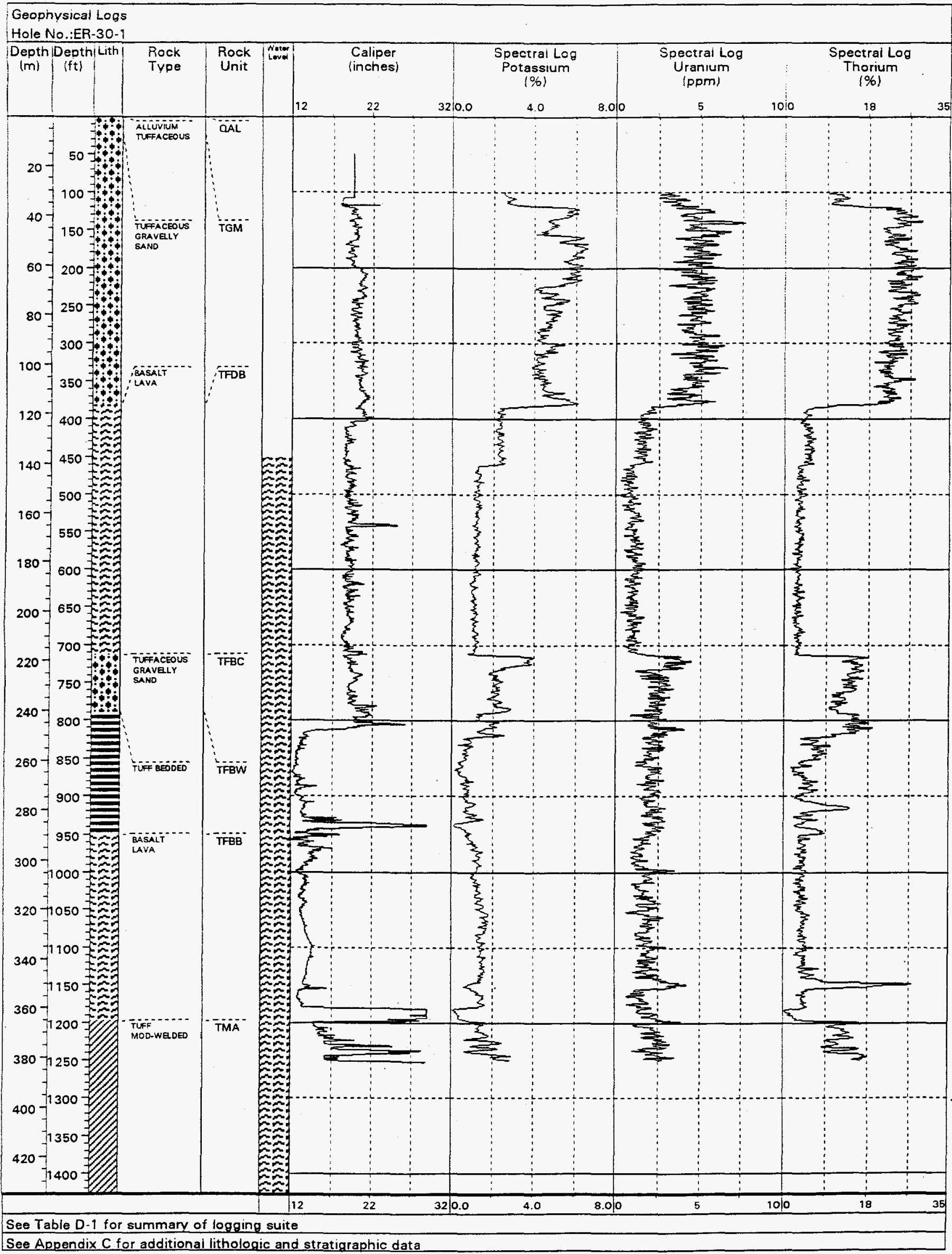




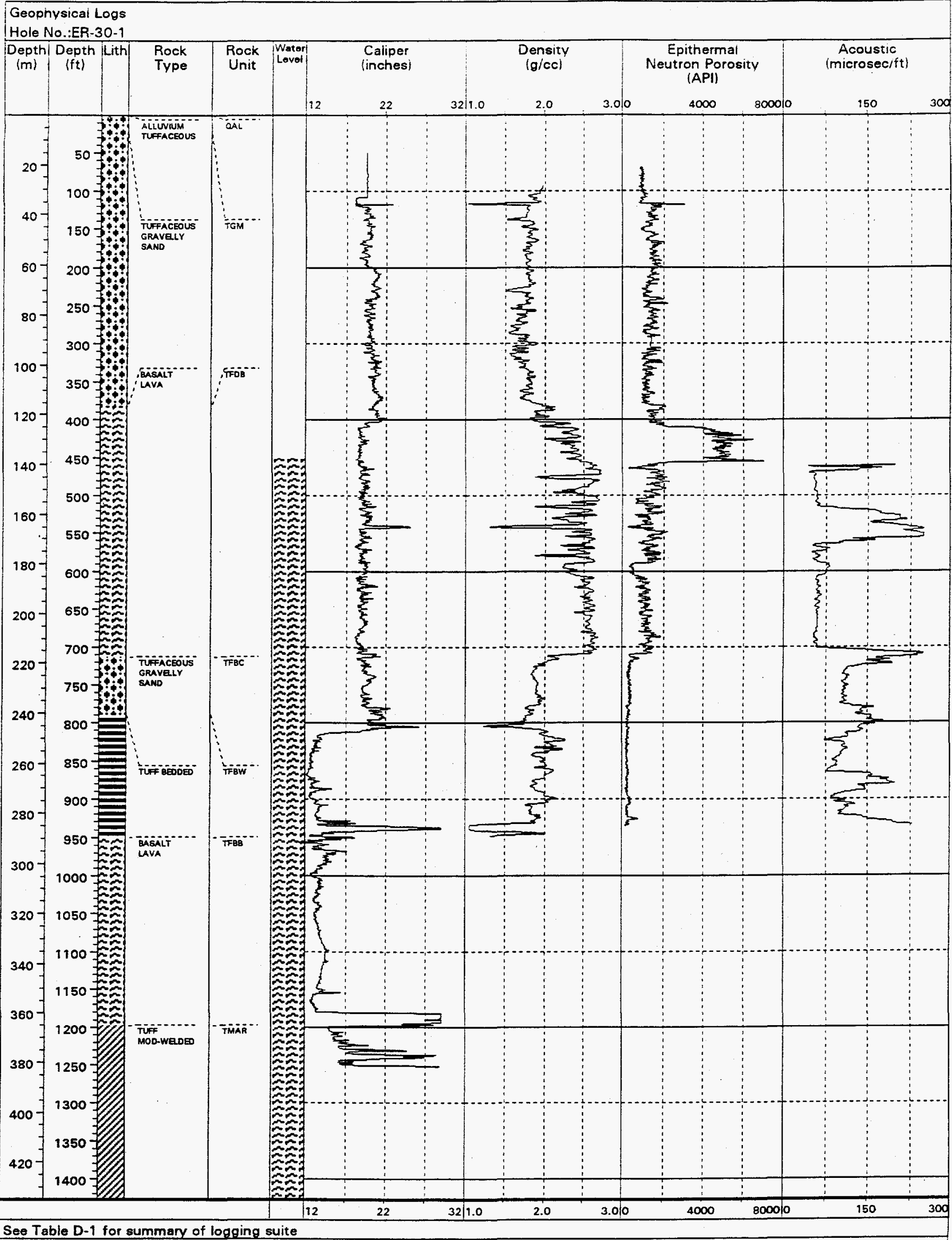

See Table D-1 for summary of logging suite

See Appendix C for additional lithologic and stratigraphic data 


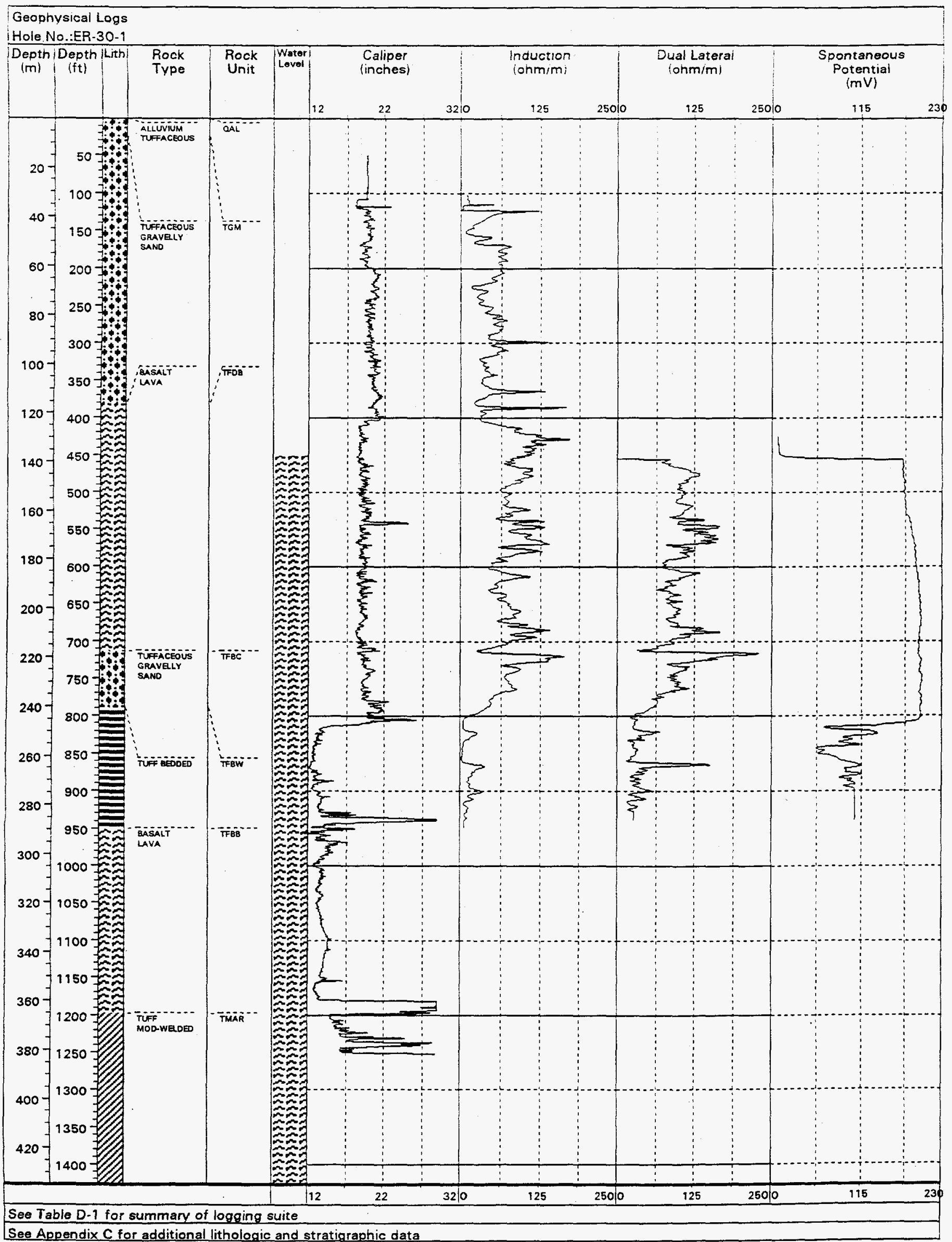

See Appendix C for additional lithologic and stratigraphic data 


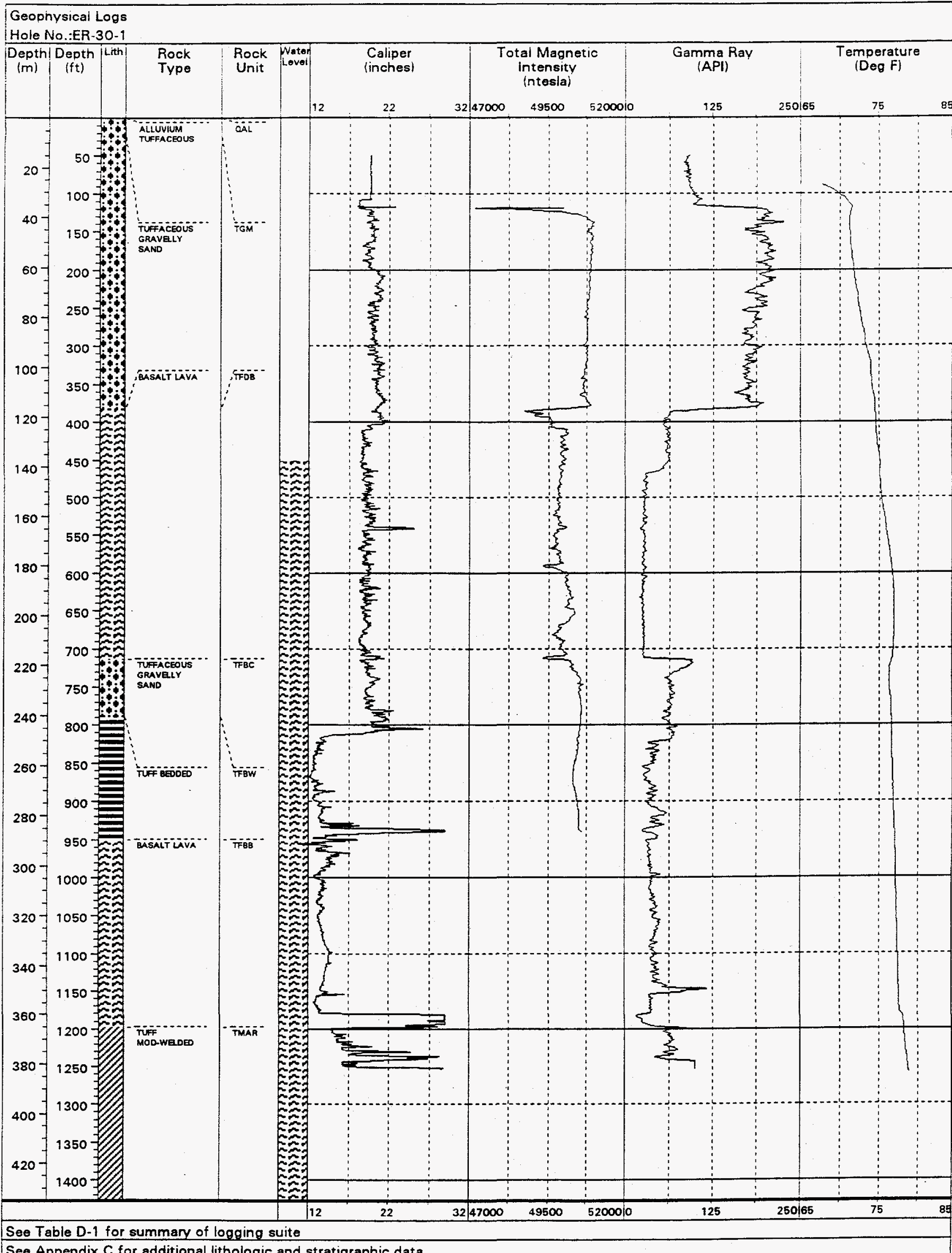

See Appendix C for additional lithologic and stratigraphic data 
Distribution List

\section{$\underline{\text { Copies }}$}

DOE/Nevada Operations Office

Technical Information Resource Center

P.O. Box 98518 ,

Las Vegas, Nevada 89193-8518

U.S. Department of Energy

Office of Scientific and Technical Information

175 Oak Ridge Turnpike

Post Office Box 62

Oak Ridge, Tennessee 37831 